
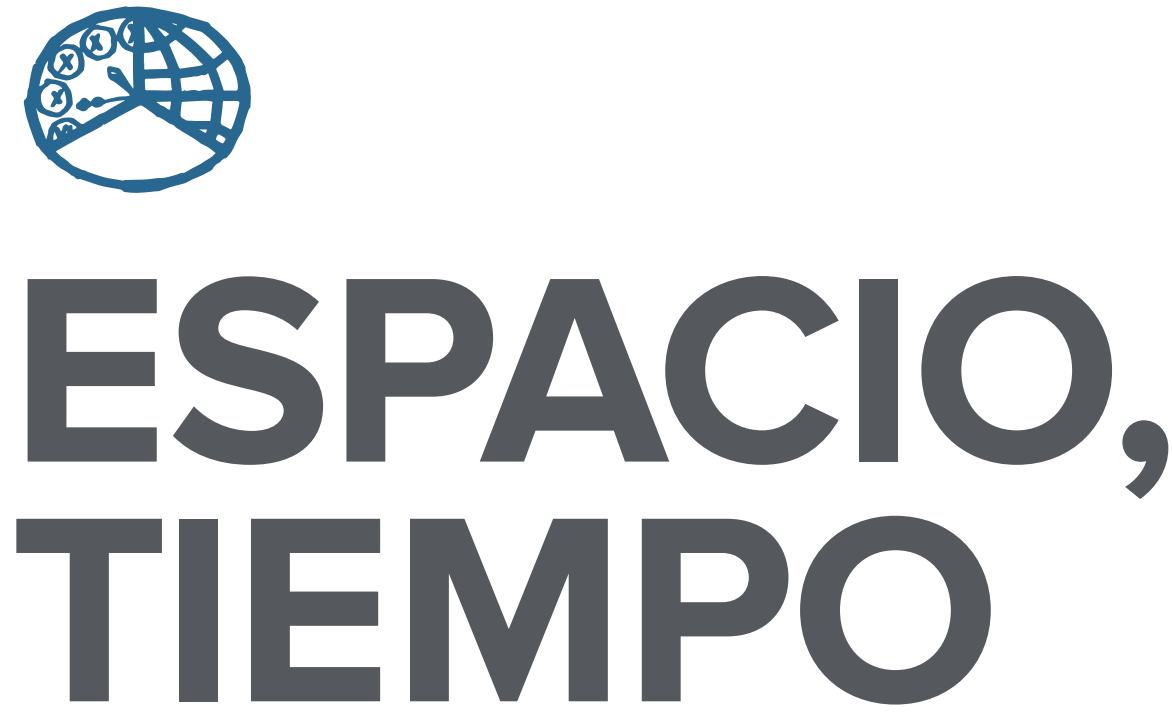

AÑO 2013

NUEVA ÉPOCA

ISSN 1130-4715

E-ISSN 2340-1478
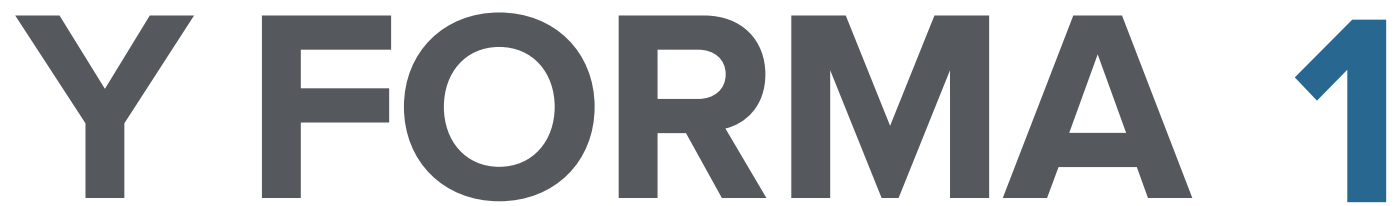

SERIE VII HISTORIA DEL ARTE

REVISTA DE LA FACULTAD DE GEOGRAFÍA E HISTORIA 

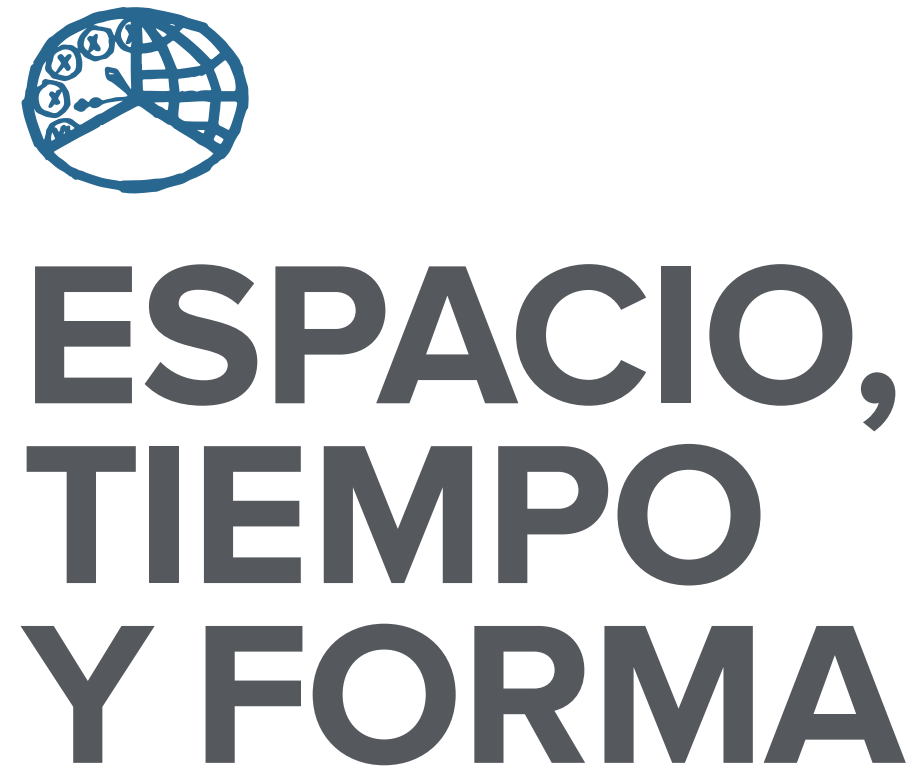

AÑO 2013

NUEVA ÉPOCA

ISSN $1130-4715$

E-ISSN 2340-1478

SERIE VII HISTORIA DEL ARTE

REVISTA DE LA FACULTAD DE GEOGRAFÍA E HISTORIA

http://dx.doi.org/10.5944/etfvii.1.2013

\section{UกED}

UNIVERSIDAD NACIONAL DE EDUCACIÓN A DISTANCIA 
La revista Espacio, Tiempo y Forma (siglas recomendadas: ETF), de la Facultad de Geografía e Historia de la UNED, que inició su publicación el año 1988, está organizada de la siguiente forma:

$$
\begin{aligned}
& \text { SERIE I - Prehistoria y Arqueología } \\
& \text { SERIE II - Historia Antigua } \\
& \text { SERIE III - Historia Medieval } \\
& \text { SERIE IV - Historia Moderna } \\
& \text { SERIE V - Historia Contemporánea } \\
& \text { SERIE VI - Geografía } \\
& \text { SERIE VII - Historia del Arte }
\end{aligned}
$$

Excepcionalmente, algunos volúmenes del año 1988 atienden a la siguiente numeración:

$$
\begin{aligned}
& \mathrm{N}^{\circ} 1 \text { - Historia Contemporánea } \\
& \mathrm{N}^{\circ} 2 \text { - Historia del Arte } \\
& \mathrm{N}^{\circ} 3 \text { - Geografía } \\
& \mathrm{N} .^{\circ} 4 \text { - Historia Moderna }
\end{aligned}
$$

ETF no se solidariza necesariamente con las opiniones expresadas por los autores.

Espacio, Tiempo y Forma, Serie vII está registrada e indexada, entre otros, por los siguientes Repertorios Bibliográficos y Bases de Datos: DICE, ISOC (CINDOC), RESH, IN-RECH, Dialnet, e-spacio, UNED, CIRC, MIAR, FRANCIS, PIO, Ulrich's, SUDOC, 2DB, ERIH (ESF).

\author{
UNIVERSIDAD NACIONAL DE EDUCACIÓN A DISTANCIA \\ Madrid, 2013 \\ SERIE VII · HISTORIA DEL ARTE (NUEVA ÉPOCA) N. ${ }^{\circ} 1,2013$ \\ ISSN $1130-4715 \cdot$ E-ISSN 2340-1478 \\ DEPÓSITO LEGAL \\ $M-21.037-1988$ \\ URL \\ ETF VII · HISTORIA DEL ARTE · http://revistas.uned.es/index.php/ETFVII \\ DISEÑO Y COMPOSICIÓN \\ Ángela Gómez Perea · http://angelagomezperea.com \\ Sandra Romano Martín · http://sandraromano.es \\ Impreso en España · Printed in Spain
}

(c) (1) (8) Esta obra está bajo una licencia Creative Commons

Reconocimiento-NoComercial 4.0 Internacional. 


\title{
SANTIAGO SERRANO (1970-1980): HACIA UNA PINTURA NO APREHENSIBLE
}

\author{
SANTIAGO SERRANO (1970-1980): \\ TOWARDS A NON-APPREHENSIBLE PAINTING
}

\author{
Óscar Muñoz Sánchez ${ }^{1}$ \\ Recibido: 22/05/2013 - Aprobado: 3/10/2013 \\ http://dx.doi.org/10.5944/etfvii.1.2013.7047
}

\begin{abstract}
Resumen
La pintura de Santiago Serrano en los años setenta, quizás la fase más brillante de toda su trayectoria, todavía no había sido estudiada desde un enfoque que conjugara la observación directa de su obra y la lectura de sus escritos inéditos. Este artículo es el resultado de una investigación sobre su trabajo artístico en aquella década, con el objetivo de averiguar las referencias, motivaciones y procedimientos que le llevaron, ya desde finales de I970, a un grado tan radical de abstracción que entronca con Malevich, Rothko, Newman o Diebenkorn. Por su particular concepción y uso del color y la materia, Serrano se distinguió claramente de otras tendencias abstractas como el informalismo o las geometrías derivadas del minimalismo, el op art o el cinetismo. Asimismo, se analiza el desarrollo de su obra en el contexto de la Pintura-Pintura, sobre todo con relación a las aportaciones de Supports/Surfaces, el grupo de Trama y los pintores italianos adscritos a la Pittura Analitica y Pittura-Pittura. Finalmente, se advierte cómo la pintura de Serrano en los setenta se ha proyectado sobre determinadas fases de su obra posterior.
\end{abstract}

\section{Palabras clave}

Arte Contemporáneo; abstracción; color; pintura; escritos de artistas; años setenta; tríptico; pintura analítica

\section{Abstract}

The painting of Santiago Serrano in the seventies, perhaps the most brilliant part of his whole production, had not yet been studied using an approach that combines the direct observation of his work and the reading of his unknown writings. This article deals with the development of his artistic work during that decade (in order to find the references, motivations and procedures which led him to such a radical level of abstraction that is connected with the art of Malevich, Rothko, Newman

\footnotetext{
1. Cuerpo Facultativo de Conservadores de Museos. Instituto del Patrimonio Cultural de España (oscar.munoz@ mecd.es).
} 
or Diebenkorn). Due to his particular conception and use of colour and material, Serrano's work was clearly different from other abstract trends like Informalism or Geometric Art derived from Minimalism, Op Art or Kinetic Art. Furthermore, the development of his work is analysed in the context of Painting-Painting, mainly with regard to Supports/Surfaces, the Spanish group Trama and Italian painters linked to Pittura Analitica and Pittura-Pittura. The way Serrano's painting of the seventies has influenced certain stages of his later artistic career is observed as well.

Keywords

Contemporary Art; abstraction; colour; painting; artists' writings; I970s; triptych; analytical painting 


\section{INTRODUCCIÓN}

Santiago Serrano (Villacañas, Toledo, I942), pintor, artista gráfico y restaurador de pintura, es una de las máximas figuras de la abstracción en España, reconocimiento que ha merecido desde que inició su espléndido ciclo pictórico de los años setenta. Siempre con rigor y discreción, se ha comprometido durante los últimos cuarenta años con el oficio de la pintura desde una triple faceta, como pintor, restaurador con taller propio y, desde los años noventa, profesor de técnicas artísticas en la Universidad de Salamanca ${ }^{2}$.

La pintura de Santiago Serrano en los setenta — quizás la fase más brillante de su producción junto con el ciclo que abarca desde I988 hasta I999-, se puede encuadrar históricamente en el fenómeno de la llamada Pintura-Pintura, que comprendería las aportaciones del grupo francés Supports/Surfaces o las de aquellos pintores italianos adscritos a denominaciones tales como Pittura Analitica y Pittura-Pittura. En España, encajarían en las coordenadas formales e ideológicas de esta corriente el grupo de Trama y, de un modo parcial, Jordi Teixidor y algunos artistas del llamado grupo sevillano, como Gerardo Delgado y Juan Suárez.

Partiendo de una pintura de encargo y de una cuantiosa producción de monotipos de asunto paisajístico en los años sesenta, Serrano dio a principios de la década siguiente un contundente giro hacia una abstracción que no esconde su raigambre en la obra de Rothko, Newman, Malevich o Mondrian, y que mantiene al mismo tiempo un aire inconfundible, un sello de autor cuyos orígenes y elementos específicos he procurado desentrañar, recurriendo a la observación directa de un gran número de obras, a la lectura y transcripción de los escritos del artista, hasta ahora inéditos; a la realización de una serie de entrevistas con el pintor, la consulta de su archivo fotográfico personal y el manejo de la bibliografía existente, debida sobre todo a críticos de arte.

Su etapa de los años setenta presenta una singular importancia, no sólo por la radicalidad de sus realizaciones, sino también porque durante ella sentó algunas de las características esenciales que definirían su obra artística en décadas posteriores,

2. La trayectoria de Santiago Serrano ha sido valorada como una de las más sólidas y coherentes de la pintura española de los últimos cuarenta años. Entre sus exposiciones individuales cabe destacar las celebradas en el Museo Español de Arte Contemporáneo (1981), la galería Joan Prats (1988), la galería Soledad Lorenzo (1989 y 1992), el Centro Cultural Conde Duque (1999) o el Palacio de Revillagigedo (2008), entre otras. Su obra ha estado presente en varias colectivas emblemáticas de una brillante generación de artistas que despuntó en los años setenta, como la celebrada en 1977 en la Caja de Ahorros de Alicante y Murcia; «Madrid D.F.» (1980, Museo Municipal de Madrid) y «8 pintores de Madrid» (1981, Ciudadela de Pamplona). Igualmente ha sido incluido su trabajo en algunas de las más importantes revisiones que sobre el arte español de los setenta, ochenta y noventa se han realizado: «Madrid. Años setenta. 23 artistas» (1991), «Por la Pintura. Colección Miguel Marcos» (1991), «Los Años Pintados» (1995 y 2001), «Imágenes de la Abstracción: pintura y escultura española 1969-1989» (1999), «Los setenta: una década multicolor» (2001), «Arte español de los años 80 y 90 en las colecciones del Museo Nacional Centro de Arte Reina Sofía», «Ut Pictura» (2001), «Abstracciones 1955-2002. Colecciones del Museo Nacional Centro de Arte Reina Sofía» (2002), etc. Más recientemente, han sido incorporadas obras suyas de los setenta en las muestras «Derivas de la geometría: razón y orden en la abstracción española (1950-1975)» (2009), «Márgenes de silencio. Colección Helga de Alvear» (2010), «Construyendo una colección. Una interpretación de la colección Fundación Botín» (2011) y «Aproximaciones I. Arte Español Contemporáneo en la Colección Helga de Alvear» (2011-2012). 
hasta llegar a sus últimas pinturas de 2012 o a las series digitales de los últimos quince años ${ }^{3}$.

La infancia, adolescencia y primeros años de juventud de Santiago Serrano transcurrieron en la madrileña zona de Usera, que durante los años cincuenta y sesenta creció como un barrio de aluvión donde se concentraron familias de inmigrantes llegadas desde muchas partes de España. Su acercamiento autodidacta al arte y su formación como pintor fueron notoriamente distintos de lo que había sido y todavía continuaba siendo el currículo habitual en los inicios de muchos artistas, marcados por unos años de aprendizaje académico en una Escuela de Bellas Artes.

\section{DESVELANDO LA ABSTRACCIÓN (1968-1971)}

A finales de 1967 Santiago Serrano recibió una beca de la Fundación Juan March para estudiar en París, adonde viajó con el objetivo de ver galerías y exposiciones, ejercitarse en alguna academia y adquirir una cierta información que le permitiera redefinir su camino como pintor ${ }^{4}$. La estancia en París entre marzo y mayo del 68 significó un cambio sustancial en su orientación estética. Trascendental fue su breve paso por la Académie Julian donde impartía clases Antonio Guansé, maestro que le hizo descubrir procedimientos y estrategias de trabajo que sobrepasaban con mucho la pintura realizada por el joven Serrano hasta entonces, lanzándole al terreno de lo abstracto 5 . Serrano fue testigo de las revueltas estudiantiles y de la inmediata represión de las autoridades francesas; espectador sorprendido e inconsciente del abrumador peso y repercusión de aquellos acontecimientos sobre la vida cultural europea de los años siguientes. Detenido y expulsado por la policía francesa, regresó a Madrid llevando consigo la serie de trabajos realizados en la Académie Julian y en su hotel de París. De aquel conjunto sobresalía, por su novedad respecto al repertorio que había marcado su trayectoria anterior, una serie de papeles y cartulinas dotadas de un discreto acento expresionista, confeccionadas con trozos de papel higiénico encolados sobre el soporte y pintados con acuarela y gouache, dejando chorrear un poco la pintura. La composición guardaba reminiscencias de un paisaje muy elemental — «una sensación paisajística» ${ }^{6}$ : una línea de horizonte que delimitaba dos

3. Debido a ello, este artículo se centra fundamentalmente en la trayectoria del pintor durante aquella década. Remito al lector interesado a la tesis doctoral que próximamente defenderé sobre la totalidad de la obra artística de Santiago Serrano, que abarca su pintura y obra sobre papel desde mediados de los años sesenta del pasado siglo hasta la actualidad. Tesis dirigida por Víctor Nieto Alcaide, Departamento de Historia del Arte de la UNED.

4. Previamente, su contacto con el arte extranjero se había limitado a unas cuantas visitas a exposiciones en Madrid; entre ellas, una que ofreció un panorama bastante representativo de la pintura norteamericana de aquel momento: USA Arte actual. Colección Johnson, celebrada en el Casón del Buen Retiro entre junio y julio de 1964. Allí pudo ver por primera vez obras de Robert Rauschenberg, Ellsworth Kelly, Sam Francis, Richard Diebenkorn, Robert Motherwell, Ad Reinhardt y Josef Albers, entre otros pintores, tanto figurativos como abstractos, que completaban una extensa nómina de la que no obstante estaban ausentes Mark Rothko y Clyfford Still. La exposición constaba de un centenar de obras de pintores vivos en 1962, año en que se había formado la colección. Véase usa Arte actual. Colección Johnson, Madrid, Ministerio de Educación Nacional, Dirección General de Bellas Artes, 1964.

5. Archivo de la Fundación Juan March (AfJM), Serrano, Santiago: «Estudio de las actuales corrientes en pintura en París y realización de una serie de cuadros», abril-mayo de 1968.

6. Entrevista del autor con Santiago Serrano en su estudio, Madrid, 7 de abril de 2010. 
planos monocromos impregnados de color rosa o azul, y un recuadro de papel pegado en la parte superior?

Unos meses después de haber regresado a Madrid, Serrano decidió presentar sus nuevas obras en una de las galerías con mejor reputación en la capital: Juana Mordó ${ }^{\text {. La galerista }}$ recibió al joven pintor, observó las cartulinas y se quedó con tres de ellas en depósito ${ }^{9}$. Mordó felicitó a Serrano por la calidad de su trabajo y le manifestó

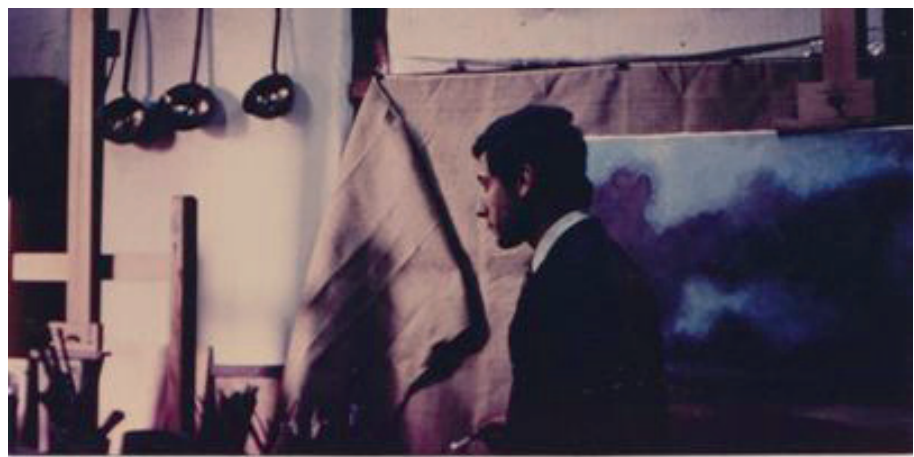

FIGURA 1. SANTIAGO SERRANO EN SU TALLER, MADRID, 1969-1970 Archivo de María Carballido. que desearía ver aquellas mismas obras en un formato mucho mayor, de alrededor de dos metros. Serrano contestó que no podía acometer semejante trabajo porque carecía de dinero y de recursos materiales para llevarlo a cabo. Quizás el mayor favor que le hizo entonces la galerista fue presentarle a José María Moreno Galván, uno de los críticos de arte con mayor autoridad e influencia en España entre los años cincuenta y setenta, quien siguió desde entonces con gran atención el devenir de la obra de Santiago Serrano, impulsó en I973 la organización de una exposición individual del artista en la galería Grosvenor y escribió dos de los más tempranos y certeros textos que se han publicado sobre su pintura ${ }^{\text {Io }}$.

Del relato que proporciona el propio artista y de una observación atenta de las escasas obras que han quedado de aquel momento, se desprende que el tránsito de Santiago Serrano a la abstracción no fue sencillo, directo ni lineal, ya que a su vuelta de París, todavía cultivó durante algún tiempo una pintura de interiores domésticos y una figuración de tendencia expresionista, en la que encauzaba su desahogo frente a una situación personal de profunda crisis e insatisfacción ${ }^{\text {II }}$ (FIGURA I).

7. En qué grado pudieron influirle algunas de las exposiciones que había visto en París, justo en el momento de producirse tal cambio de orientación, es una pregunta a la que él mismo responde sin excesiva seguridad: «Destacaría unas cosas de Feito, que vi en la galería lolas de París, y otra exposición de Luis Fernández, también en París, que me pareció preciosa, sobre todo las marinas con barquitos». Entrevista del autor con Santiago Serrano en su estudio, Madrid, 21 de abril de 2010.

8. Véase xxv Aniversario de la galería Juana Mordó (1964-1989) (catálogo de la exposición). Madrid, Círculo de Bellas Artes, 1989.

9. Serrano conserva el resguardo que acredita tal depósito, con fecha de 13 de noviembre de 1968.

10. Moreno Galván era uno de los mayores comentaristas del desarrollo de la abstracción en España, a través de numerosas críticas periodísticas y libros como «Introducción a la pintura española actual» (1960), «Autocrítica del arte» (1965) y «Pintura española. La última vanguardia» (1969). Véase BozAL, Valeriano: Arte del siglo xx en España. Pintura y escultura 1939-1990. Madrid, Espasa Calpe, 1995, pp. 365-367.

11. En una entrevista para $A B C$ en 1973, Serrano resumía cómo se había producido la transición desde aquellas pinturas de 1969-1970 -interiores y paisajes-, duras, claustrofóbicas y angustiadas, hacia la abstracción equilibrada y serena de principios de los setenta: «Durante una época, después de mi vuelta de París, me interesó mucho el paisaje urbano. Este paisaje se me fue simplificando, se me fue diluyendo, se me fue quedando vacío de argumentación. (...) Yo he pasado, como tantos, de la figuración a la abstracción. Durante un tiempo realicé unas figuras que estaban enmarcadas en una ventana, en una puerta, en un balcón (...) Fui simplificando, eliminando anécdota, hasta llegar a hacer un cuadro con un reborde que tenía como un sentido especial. Empezó a importarme la materia y a partir de ahí me fui introduciendo en la obra presente». FERnÁNDEZ-BRASO, M.: «La eliminación ornamental de Santiago Serrano», $A B C$, Madrid, 6 de octubre de 1973, pp. 61-62. 
En el transcurso de I970 Serrano inició una serie de ensayos con formas geométricas elementales, que suponían la antesala de la obra expuesta en la galería Amadís en mayo del año siguiente. Recortaba en papel triángulos, cuadrados, círculos, y los adhería a una cartulina rígida de $65 \times 50 \mathrm{~cm}$. Arrancaba a continuación estas plantillas de modo que quedaran huellas y jirones del papel sobre el soporte, y añadía finalmente una veladura de acuarela: «Esta serie de tanteos me fue llevando a una depuración, a ir quitando lo que me sobraba» ${ }^{12}$.

A principios de 1971 Serrano dio comienzo el Cuaderno 197I-1973, un dietario en el que empleó una metodología y un registro sistemático del trabajo en

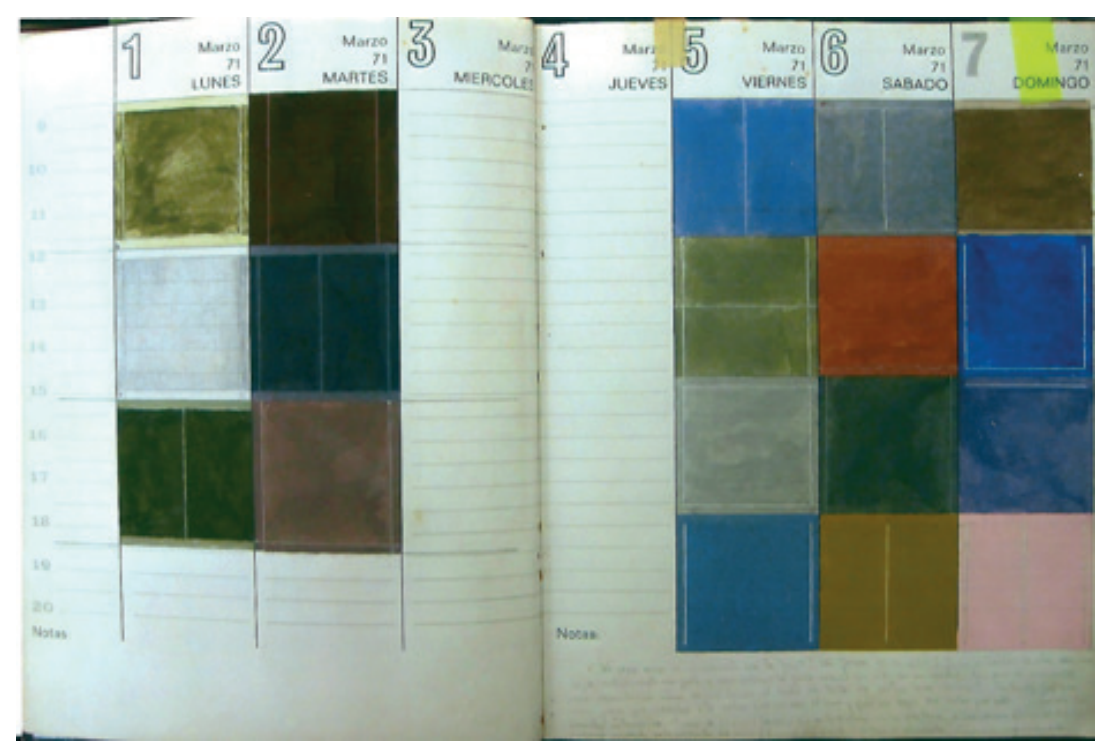

FIGURA 2. CUADERNO 1971-1973

Gouache y acuarela sobre papel. Ejemplar original. Colección del artista. curso, que le ayudara a definir las herramientas pictóricas que estaba buscando. Hilvanó un muestrario de diminutos bosquejos y apuntes, configurando paneles o mosaicos de «celdas-cuadro» que cubren medias páginas o páginas casi enteras, con escasas anotaciones manuscritas en la zona inferior o en los márgenes ${ }^{13}$. Salpicó las páginas de notas e instrucciones muy precisas dirigidas a sí mismo, concernientes a cada uno de los elementos y valores que entran en juego durante el proceso pictórico: elección de los soportes, imprimaciones, pigmentos, aglutinantes, composición; permitiéndose muy pocas veces introducir alusiones a su vida privada, su estado de ánimo o su relación con el prójimo (FIGURA 2).

El Cuaderno se abre con los preliminares del proyecto de exposición para la galería Amadís, sala perteneciente a la Delegación Nacional de la Juventud, que un año antes había iniciado una nueva andadura bajo la dirección del pintor y crítico de arte Juan Antonio Aguirre, quien tomaba el relevo del anterior responsable, Carlos Antonio Areán. Aparte de exposiciones de pintura de Santiago Serrano (I97I),

12. Entrevista del autor con Santiago Serrano en su estudio, Madrid, 30 de septiembre de 2010.

13. Serrano brindó una sucinta descripción del procedimiento que seguía a la hora de proyectar nuevas series pictóricas. Sus palabras se ajustan bien a las pautas que revela el Cuaderno 1971-1973: «Actualmente no trabajo a golpe de ciego, sino con método y con tanteos previos. Para realizar un cuadro lo primero que hago es abocetarlo en una medida muy pequeña, luego lo llevo a otra medida mayor, y generalmente acaba en dibujo. De este modo elijo lo que quiero y lo que interesa a mi propia pintura. En el color actúo de manera distinta: no es premeditado, sino que me dejo llevar por impulsos no explicables. Técnicamente, sin embargo, el lienzo está muy trabajado, muy pacientemente preparado». FERnÁNDEZ-Braso, M.: op. cit,. pp. 61-62. 
Carlos Alcolea (197I), Carlos Franco (I973), Miguel Ángel Campano (I972) y Mitsuo Miura (I972), se organizaron allí otro tipo de propuestas emparentadas con la escultura, la instalación y el arte conceptual, a cargo de Luis Muro (I97I), Nacho Criado (I97I), Pablo Pérez Mínguez y Carlos Serrano (I973). En muchos casos, estas muestras significaron el debut en solitario, ante el público y la crítica, de unos artistas que mantendrían una estrecha relación profesional y personal durante los años inmediatamente posteriores; en el caso de Santiago Serrano, fundamentalmente con Carlos Alcolea y Nacho Criado ${ }^{\mathrm{I4}}$.

Las tablas y cartulinas que Serrano expuso en Amadís eran el fruto de un procedimiento que incluía la acuarela, la pintura vinílica y acrílica. Si tuviéramos que efectuar la catalogación de estas obras, eludiendo la manida denominación «técnica mixta», cabría resumir la técnica empleada con la siguiente concatenación de términos: imprimación - tanto de las plantillas de papel como de la tabla forrada de tela-, estampación y arrancado de las plantillas, justo antes de que el acrílico empezara a pegarse completamente a la tabla bañada de acetato o adhesivo ${ }^{15}$.

En algunas tablas, el acetato de polivinilo se concentra en dos bandas horizontales y blancuzcas que cercan por arriba y abajo un gran recuadro central, funcionando a modo de «respiraderos»; término utilizado coloquialmente por Serrano para designar las bandas de color tenue, verticales u horizontales, que solía colocar en los laterales o en el centro de sus pinturas y acuarelas de los años setenta, aunque un recurso similar aparecerá de nuevo en algunas series de la década de 2000 - Llaves (2004), Sombra de humo (2004-2005), Silenciario (2007). El vocablo «respiradero» denota, metafóricamente, la intención de que las grandes zonas de color se articulen con suavidad y naturalidad, gradualmente, sin bordes ni perfiles duros, evitando las diferenciaciones netas y secas entre los distintos sectores de la composición, al contrario de lo que suele observarse en gran parte de la pintura más o menos situada en la órbita del constructivismo o de la abstracción geométrica. La función del «respiradero» es «humanizar» el cuadro, oxigenarlo, impregnarlo de matices y transiciones tanto en las extensas superficies de color como en los bordes que las delimitan, evitando trazar sobre la tela una estructura de contornos nítidos ${ }^{\mathrm{I}}$.

14. Véanse los anuarios que editaba la propia galería: Galería Amadís: resumen de temporada 1970-71/197172/1972-73. Galería Amadís, Madrid. Disponibles en la Biblioteca del Museo Nacional Centro de Arte Reina Sofía (MNCARS), Madrid.

15. De acuerdo con la explicación proporcionada por el artista: entrevista del autor con Santiago Serrano en su estudio, Madrid, 30 de septiembre de 2010.

16. Bastantes años después, Serrano escribiría acerca de la función que cumple el degradado tonal en su pintura: «El elemento 'vibracional' (sic) que aparece ya (hace) algunos años en las líneas que marcan, dividen, crean espacios, está manifestado por un pequeño, más bien ligero degradado del mismo color que la línea o franja, y que hace que la división de esos espacios se crea (cree) por una función más de luz/color, que solo color. Cuando en algunas ocasiones sobreponemos un elemento de color fuerte - muy contrastado- sobre (otro) claramente diferenciado de color tonal ocurre que los perfiles se marcan excesivamente (...). Degradando se crea una atmósfera que no delimita tanto y el color se serena más ayudando a que su expresividad sea menos geométrica y más pictórica. Por otra parte (ayuda a que) la relación de línea o banda y fondo se conjuguen y armonicen. Así es que esa pequeña intervención elimina la dureza y el vigor de lo duro y cortante para acercarlo a una experiencia más vital y placentera. La rigidez, por cierta blandura necesaria». Archivo personal de Santiago Serrano (ASS), Serrano, Santiago: «Cuaderno 1997-2009», febrero de 1999. 
En sus respectivas reseñas críticas a la exposición de Amadís, tanto Juan Antonio Aguirre ${ }^{17}$ como José de Castro Arines ${ }^{18}$ señalaron la afinidad de la pintura de Santiago Serrano con la de Mark Rothko, sobre la que años después insistirían otros comentaristas. Santiago Serrano vio por primera vez la pintura de Rothko, al natural, en la exposición-homenaje que el Museo Nacional de Arte Moderno de París organizó en 1972, dos años después de que muriera el pintor ruso-norteamericano. Antes de aquella visita, sólo pudo conocerla por reproducciones fotográficas en algún libro que le enseñara su entonces amigo el pintor argentino Adolfo Estrada, quien al ver el trabajo de Serrano de finales de I970 y principios de I97I, comentó cuán rothkiano le parecía. En I972, Estrada le propuso viajar con él a París para ver

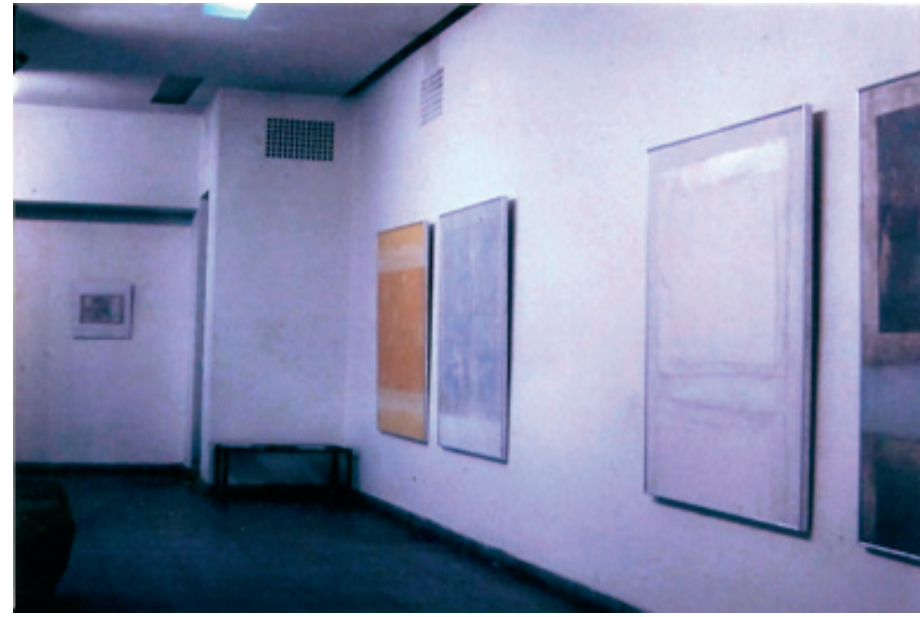

FIGURA 3. DETALLE DE LA EXPOSICIÓN INDIVIDUAL DE SANTIAGO SERRANO, SALA AMADÍs, 1971 Archivo del artista.

aquella exposición retrospectiva, que causó en Serrano un hondo impacto, apreciable sobre todo en su producción de aquel año y en la de i973.

Bastantes de las composiciones de la serie Amadís sugieren imágenes de porta-fotos que no portan ninguna fotografía o de interiores de escasa profundidad y despojados de contenido icónico; soportes-receptáculo que se nos ofrecen tal cual son, que no soportan ni contienen nada salvo su propia desnudez, en consonancia con la definición, escueta y certera, que Pedro Antonio Urbina aventuró de la pintura de Serrano en el catálogo: «una realidad desnuda de efectismo superficial; algo así como si no tuviera circunstancias ni apoyatura».9 Sin embargo, el tratamiento que Serrano dio a las superficies, semejantes a lajas de piedras duras sin pulimentar, difiere de las calidades que pueden apreciarse en obras aparentemente similares de Rothko, Malevich o Albers (FIGURA 3).

Curiosamente, tanto en algunas de las reseñas publicadas con motivo de la exposición en Amadís, como en otras referidas a la exposición de 1973 en la galería Ovidio, hubo gacetilleros que vieron en la pintura de Santiago Serrano una pervivencia y renovación, si cabe limitada y comedida, de la estética informalista ${ }^{20}$. Para

17. Aguirre, Juan Antonio: «Santiago Serrano», Artes, 117 (1971), p. 23

18. De Castro Arines, José: «El espacio pictórico de Serrano», Informaciones de las Artes y las Letras, Madrid, 20 de mayo de 1971, p. 11.

19. URbinA, Pedro Antonio: Santiago Serrano, Madrid, Galería Amadís, 1971; y «Santiago Serrano», en Santiago Serrano, Barcelona, sala de arte Ausias March, El Corte Inglés, 1973.

20. «Después de contemplar la exposición de Santiago Serrano, con la que se inaugura la galería Ovidio, de Madrid, el espíritu del espectador, del gacetillero, en este caso, sale reconfortado pensando que existen fundadas esperanzas para la continuación, no mimética, del informalismo en nuestro país. (...) Este o aquel aspecto de un cuadro de Santiago Serrano puede traernos remembranzas de algunos maestros del pasado. Pero, en su concepción 
Juan Antonio Aguirre, el interés de aquellas imágenes radicaba «en un punto intermedio entre la factura no-aséptica del informalismo y la relación ilusionista de tres dimensiones que caracteriza a gran parte del espacialismo ${ }^{2 \mathrm{II}}$. El artista perseguía en aquel entonces unas imágenes cuya materia y textura fueran cada vez más adelgazadas y livianas, fruto de un procedimiento manual en el que predominaran factores mecánicos y aleatorios - si bien controlados intuitivamente por el autor-, sobre la expresión inmediata de las emociones; un método de trabajo, por tanto, exento del gesto personal, subjetivo, dramático y a menudo apasionado que animaba la mano del pintor adscrito a la estética del informalismo o la «Pintura Otra», cuyos coletazos tardíos aún podían verse en las salas de exposiciones españolas ${ }^{22}$.

\section{BUENOS AIRES, 1971}

Santiago Serrano y su esposa María Carballido se desplazaron a Buenos Aires en el verano de I97I. Por medio de su suegra Esmeralda Almonacid, reconocida escenógrafa y ambientadora del cine argentino ${ }^{23}$, Serrano conoció a varias personalidades de la vida cultural y artística de aquel país: el arquitecto Clorindo Testa, el pintor Rómulo Macció, el escritor Pepe Bianco y el crítico literario Enrique Pezzoni, entre otros $^{24}$. Esmeralda preparó a Serrano un estudio en su casa de Boulogne sur Mer, localidad a pocos kilómetros de Buenos Aires con hermosos y grandes edificios ${ }^{25}$. En lo artístico, este breve período proporcionó nuevos bríos a Serrano, inspirando algunas de sus pinturas más singulares de los años setenta. Fue una época de

unitaria, en la síntesis alcanzada por el autor, la obra que se nos ofrece en Ovidio resulta un limpio y positivo paso al frente en el camino del informalismo, hoy soterrado por el alud del hiper, del neo y demás hijuelos del realismo capitalista», A.B., «Santiago Serrano», Gazeta del arte, 1973, pp. 8-9.

21. Aguirre, Juan Antonio: op.cit. p. 23.

22. Cabe apreciar, sin embargo, ecos del informalismo en varios bocetos de pequeñas dimensiones ejecutados por Serrano en 1975, algunos de ellos reunidos en el cuaderno Lecturas 1974-1980, donde la carga y aglomeración de materia amasada en gruesos repliegues se hace más evidente. Son obras pequeñas que, significativamente, el artista desechó de cara a su plasmación en soportes de dimensiones mayores, dado que nunca se sintió del todo cómodo ni identificado con ellas. Lecturas 1974-1980 es un libro-cuaderno de formato cuadrado que consta de 33 cartones y dos tapas de cartón grueso, atravesadas en cuatro ranuras laterales por cintas rojas que se pueden anudar para cerrarlo. Tal y como reza la primera página interior — «33 lecturas»—, cada cartón soporta una lectura, una propuesta visual articulada mediante la yuxtaposición de pequeñas unidades rectangulares de cartulina tratadas con acuarela, lápices de colores, incisiones y acrílico. Al igual que Cuaderno 1971-1973, Lecturas constituye un repertorio, un muestrario en el que se condensa una parte considerable de la pintura y de la copiosa producción de acuarelas que realizó Serrano en la segunda mitad de los setenta.

23. Véase BeCCACECE, Hugo: «Un dibujo en la piedra. El adiós a Esmeralda Almonacid, inolvidable escenógrafa del cine nacional», La Nación, Buenos Aires, 27 de agosto de 2011. Disponible en http://www.lanacion.com. ar/1401045-un-dibujo-en-la-piedra

24. Esmeralda Almonacid (1922-2011), por quien Santiago Serrano siempre ha profesado gran admiración y respeto, pertenecía a una familia de prestigio y era sobrina de Ricardo Güiraldes, autor de la novela Don Segundo Sombra. Desde muy joven, gracias a la relación que existía entre su familia y la escritora Victoria Ocampo, estuvo ligada al entorno de la revista Sur, siendo amiga de Alejandra Pizarnik, Juan José Hernández, José Bianco y Enrique Pezzoni, entre otros críticos y literatos.

25. «El estudio era pequeño, con una gran vidriera y vistas al jardín. Dos paredes de cristal en ángulo recto, del suelo al techo: podría tener cinco o seis metros de profundidad por tres metros de ancho». Entrevista del autor con Santiago Serrano en su estudio, Madrid, 30 de septiembre de 2010. 
exaltación vital que le hubiera gustado prolongar y exprimir más, en la que disfrutó de una agradable vida familiar, señalada con el nacimiento de su primer hijo, Pablo.

Adolfo Estrada ofreció a Serrano la posibilidad de exponer con él en una importante galería de Buenos Aires, una invitación que finalmente no cuajó ${ }^{26}$. Sin embargo, pronto se le presentó la oportunidad de realizar una exposición en una lujosa tienda de decoración llamada Snob, perteneciente a unos amigos de Esmeralda y situada en una de las calles más prestigiosas de la capital, cerca del céntrico barrio de Recoleta. Uno de los mayores atractivos que brindaba Buenos Aires al joven pintor era la abundancia de material artístico que podía adquirir a bajo coste. Serrano hizo acopio de gran cantidad de acuarelas, acrílicos y papeles; compró tubos

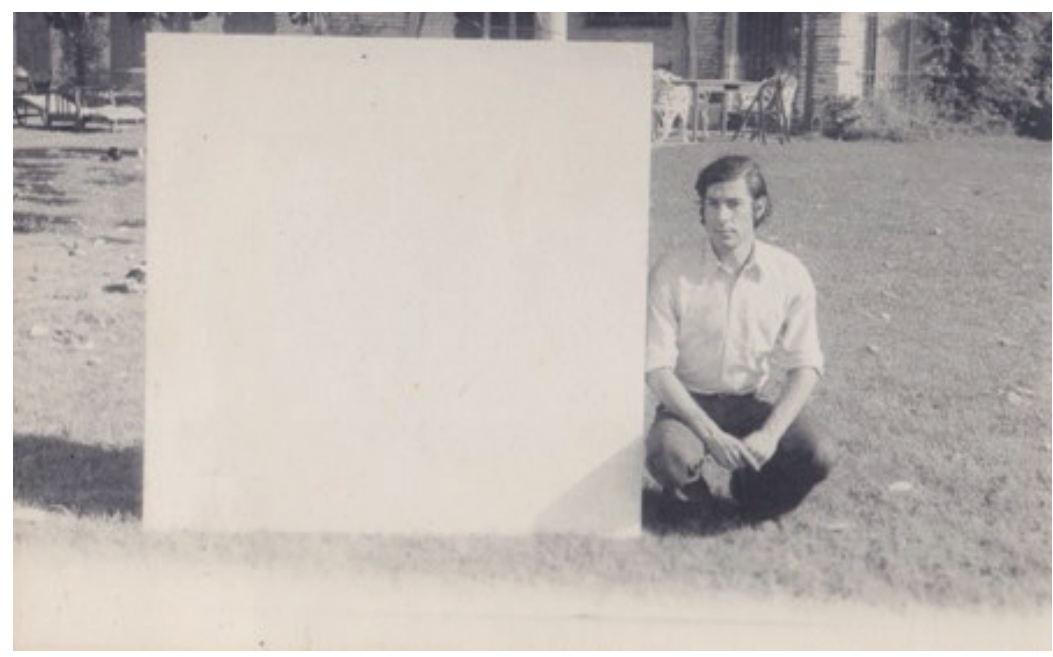

FIGURA 4. SANTIAGO SERRANO, JUNTO AL CUADRO BLANCO QUE PINTÓ PARA UNA COLECCIONISTA PARTICULAR. BUENOS AIRES, 1971 Archivo de María Carballido.

por docenas y se encerró para hacer pantones y estudiar el color. Le gustaba observar y retener los matices de la atmósfera en el atardecer, hacia las seis de la tarde. Boulogne se asomaba al río, aunque estuviera lejos. El sol se ponía por la parte que daba a su taller, y a través de las cristaleras podía ver un crepúsculo de un rosa un poco sucio y terroso. La extrema sensibilidad hacia los cambios de luz y de color en la atmósfera se puede rastrear en muchas de las cartulinas de pequeño formato que realizó Santiago Serrano en los años setenta, especial-

mente en I974 y I975, algunas de las cuales fueron después trasladadas a soportes de mayores dimensiones: «Uno de los cuadros que pinté en Buenos Aires se llamaba Buenos Aires 7:30, porque reflejaba el estado del cielo a esa hora del atardecer, un cielo amarronado, violáceo, rosado, de un color extrañísimo» ${ }^{27}$.

De la exposición en Snob, inaugurada en la tarde del in de octubre de i97I, se editó un pequeño catálogo con un texto de presentación a cargo de Enrique Pezzoni (Buenos Aires, I926-I989), quien atribuyó «libertad y autonomía» a los cuadros de Serrano, destacando su capacidad de introducirnos en otra realidad paralela a la del mundo circundante ${ }^{28}$. De los diminutos bocetos correspondientes a la estancia

26. Entre el 6 y el 23 de octubre de 1971, Estrada expuso su obra en la galería Bonino de Buenos Aires.

27. Entrevista del autor con Santiago Serrano en su estudio, Madrid, 30 de septiembre de 2010.

28. "Las telas de Serrano inauguran: abren el espacio del cuadro, la tierra prometida donde todo es nuevo, donde nada ha sido metamorfoseado, donde nada necesita el correlato del mundo exterior para justificarse. (...) La luz transita libre, confiada a sí misma, en las telas: se expande, se transforma, se profundiza, se superpone, se aposenta en napas sólidas y a la vez volátiles». Pezzonı, Enrique: Santiago Serrano, Buenos Aires, galería Snob, 1971; y Santiago Serrano, Barcelona, sala de Arte Ausias March, El Corte Inglés, 1973, s.p. 
en Buenos Aires, plasmados en el Cuaderno I97I-1973, Serrano apenas llegó a materializar algunos en formatos grandes. Caso excepcional fue un encargo privado, consistente en una pintura de notable tamaño destinada a decorar el dormitorio de una coleccionista.

A través de Esmeralda, Serrano tenía acceso a un tipo de gente culta y adinera$\mathrm{da}$, procedente de familias de terratenientes o financieros, con un gusto exquisito y buenas colecciones de arte en las que fácilmente podían hallarse cuadros de Monet, Modigliani, Rouault, Solana, etc. Serrano pintó un cuadro que podría medir I $60 \times$ I60 cm. y que iría colgado frente a los pies de una cama. Podemos hacernos una idea de sus dimensiones gracias a una fotografía en blanco y negro en la que Serrano posa junto al mismo (FIGURA 4). La intensa luz natural con que se tomó la foto, al incidir frontalmente en la obra, impide la correcta apreciación de una imagen que conforme al testimonio del artista era sumamente leve e inmaterial, y que según recuerda María Carballido, contenía la superposición de dos tipos de blanco ${ }^{29}$. La consecución de una pintura casi desprovista de materia, dotada de una extrema levedad, es uno de los empeños que refleja fielmente el Cuaderno I97I-I973 a través de los diminutos bocetos que pueblan sus páginas. Una de las anotaciones, que glosa los bosquejos del último trimestre de 1972, no deja lugar a dudas: «Tratar de que la materia no existiera» ${ }^{\circ}$.

En varios cuadros y cartulinas de i97I que empezó a preparar en Buenos Aires, el tratamiento de la superficie a la manera de una pared que cubre la totalidad del encuadre se impuso con radicalidad, con un carácter seco y absoluto que negaba cualquier atisbo decorativo o de búsqueda de belleza. Serrano sólo ha conservado en sus fondos unas pocas obras de este tipo; alguna de ellas, de composición muy similar a la de varias pinturas de Barnett Newman - Be I (1949) (de la cual Newman realizó otra versión en I970), y The Third (I962) ${ }^{31}-$ en cuya opacidad rebota la mirada del espectador.

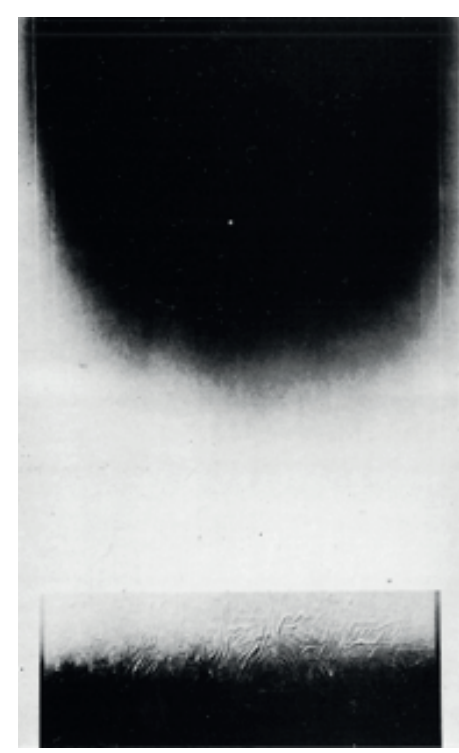

FIGURA 5. SIN TÍTULO, 1973 Vinílico, acuarela y aerógrafo sobre tabla. $170 \times 93 \mathrm{~cm}$. Archivo del artista.

\section{PAISAJE SIMBIÓTICO/PAISAJE OSMÓTICO (1972-1975). EL PARANGÓN CON ROTHKO}

El ascendiente de Rothko se tornó más claro en las obras expuestas en la galería Ovidio en octubre de 1973, identificables por unos patrones de composición que Serrano ya había ensayado en varias tablas de I972 todavía bajo el título Serie Amadís. Uno de los esquemas de distribución espacial más repetidos consta de una

29. «Me gustó mucho, y qué pena no haber seguido con esa racha, porque creo que ese cuadro era de una belleza... era inmatérico (sic)». Entrevista del autor con Santiago Serrano en su estudio, Madrid, 30 de septiembre de 2010.

30. (ASS), Serrano, Santiago: Cuaderno 1971-1973. Ejemplar original en poder del artista.

31. Barnett Newman: a catalogue raisonné, New York, The Barnett Newman Foundation; New Haven and London, Yale University Press, 2004. Números de catálogo 34 y 83 respectivamente. 
extensión intermedia, vacía y de anchura variable, bajo la cual se asienta una masa densa, dotada a veces de una considerable carga de materia. Por encima del vacío intermedio gravita otra masa de menor consistencia que nos hace pensar, si recurrimos a similitudes con la fenomenología atmosférica, en un nubarrón o en una mancha ominosa que descendiera lentamente sobre la tierra. La tabla que Serrano envió a la Bienal de Baracaldo ${ }^{32}$ de 1973 (FIGURA 5) -donde participó a propuesta del crítico de arte Santiago Amón- presenta esa triple compartimentación de arriba abajo: una masa gaseosa e ingrávida de impenetrable negrura, un espacio vacío y un rectángulo de materia arrugada y consistente; un tipo de distribución bidimensional que, al igual que algunas pinturas de Rothko, guarda una sorprendente similitud con determinados modelos de iconografía cosmogónica presentes en códices medievales, como la imagen del primer día del Génesis recogida en el Octateuco bizantino (siglo xil), donde el autor se esforzó en hacer visibles los primeros momentos de la creación mediante una representación separada de sus componentes, repartidos en secciones horizontales sobre un plano que tiende a la verticalidad: el cielo que irradia la fuerza divina; la tierra y las tinieblas sobre el abismo ${ }^{33}$.

Tanto en la tabla para la Bienal de Baracaldo, como en las pinturas y acuarelas que integran la serie Ovidio (FIGURA 6), pervive el rescoldo o la huella esencial de un paisaje imaginario, si nos atenemos a lo que revelan las breves glosas del autor en el Cuaderno I97I-I973, hechas al pie de los diminutos bosquejos: «Serie Simbiosis y paisaje simbiótico. Ósmosis y paisaje osmótico» ${ }^{34}$. El segundo término, ósmosis, tomado de la biología celular y referente al paso de una solución de mayor concentración a otra de menor concentración a través de una membrana semipermeable, conocería un empleo más específico y profundo en la pintura de Santiago Serrano de 1976 y 1977.

A mi juicio, la manida vinculación de Santiago Serrano con Mark Rothko, en la que han incidido algunos comentaristas ${ }^{35}$, se justifica sólo en parte dado que se

32. Catálogo de la $/ 1$ Muestra de Artes Plásticas, Ayuntamiento de la Anteiglesia de Baracaldo, mayo-junio de 1973. La tabla de Santiago Serrano se encuentra reproducida en las páginas interiores.

33. Según ha señalado Vega Esquerra al indagar las raíces cosmogónicas y religiosas de la pintura de Rothko. Véase Vega Esquerra, Amador: Sacrificio y creación en la pintura de Rothko. La vía estética de la emoción religiosa. Madrid, Ediciones Siruela, 2010, pp. 80-82.

34. La noción de paisaje siguió latiendo en gran parte de la obra de Santiago Serrano hasta mediados de los años ochenta, e incluso más allá, hasta llegar al presente. Véase Logroño, Miguel: «Santiago Serrano. Paisaje de la pintura», Diario 16, Madrid, 22 de mayo de 1981, p. 28. En sus cuadros y cartulinas de 1973, Serrano recurrió al aerógrafo y la acuarela para conferir una extraña ingravidez a las masas oscuras.

35. Aguirre, Juan Antonio: op. cit. p. 23; Del Castillo, A.: «Santiago Serrano, en la sala de arte Ausias March», Diario de Barcelona, Barcelona, 18 de noviembre de 1973; Moreno GalváN, José María: «Santiago Serrano», Triunfo, Año xxvIII, n. ${ }^{\circ}$ 576, Madrid, 13 de octubre de 1973, pp. 79-80; Hernando Carrasco, Javier: «Expresionismo 
circunscribe a unos cuantos rasgos únicamente detectables en determinados momentos de su trayectoria. Aparte de los ecos rothkianos ya indicados en las pinturas de 1972, hay otros que resuenan con mayor claridad en los cuadros y cartulinas de la serie Ovidio (I973), donde la composición, armada con dos o tres franjas que flotan una sobre otra, que parecen avanzar o retroceder según el grado de saturación que haya impuesto el pintor a la mancha, revela similitudes claras con la producción del pintor ruso-estadounidense en los años cincuenta y sesenta, aquellas pin-

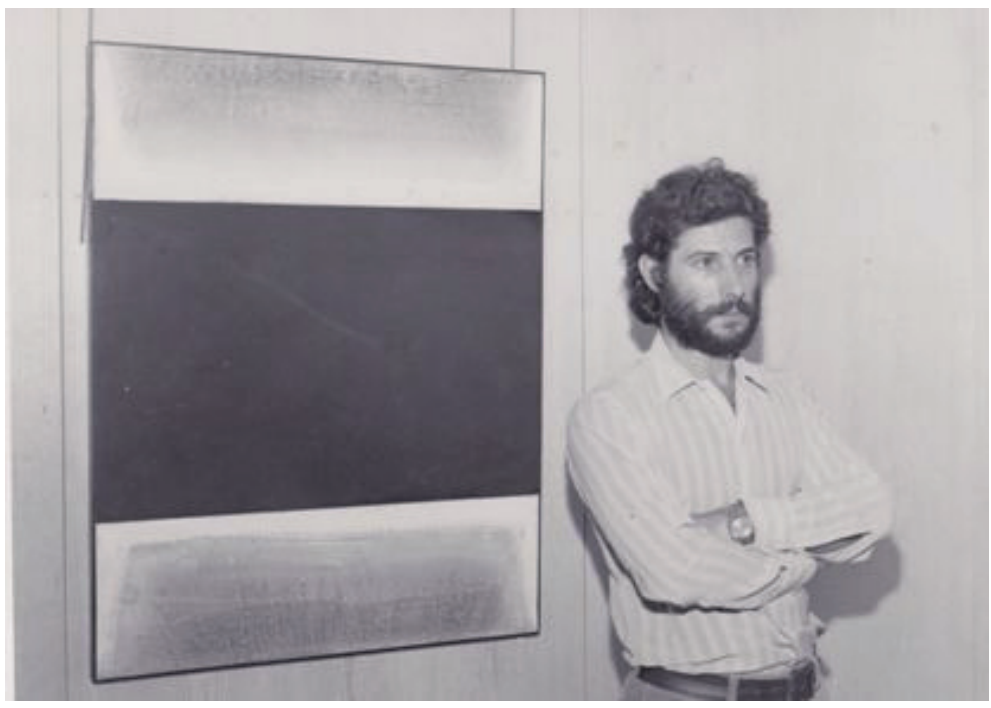

FIGURA 7.SANTIAGO SERRANO EN LA INAUGURACIÓN DE SU EXPOSICIÓN INDIVIDUAL EN LA GALERÍA OVIDIO, 1973 Archivo del artista. turas que absorben al espectador hacia un espacio totalizador y unitario. Algunas acuarelas de 1972 se adscriben igualmente a ese tipo de configuración espacial, aunque carecen de las calidades esponjosas e ingrávidas que revisten las manchas de color en las pinturas clásicas de Rothko. Al contrario, las imágenes de Serrano aparentan una mayor dureza y consistencia, siendo por otra parte evidente la distinta repercusión que sobre el espectador ejercen los formatos grandes y envolventes de Rothko, frente al tono íntimo de las pequeñas cartulinas o cuadros de mediano tamaño que en aquella época pintaba Santiago Serrano ${ }^{36}$.

Las tres exposiciones individuales de I973, en las galerías Grosvenor (Madrid), Ovidio (Madrid), y Ausias March (Barcelona), significaron la confirmación de Santiago Serrano como una figura digna de atención y seguimiento en el panorama de la pintura española (FIGURA 7). A propósito de la individual en Ovidio, que inauguraba la andadura de esta galería madrileña donde expondrían muchos de los más representativos artistas españoles de los años setenta y ochenta, José María Moreno Galván escribió: «Santiago Serrano pertenece a esa casta de artistas que se atreven a situar a su arte - a su pintura, en este caso- en el último y radical estado problemático de su preocupación, sin conceder en ningún momento agarraderas piadosas para el espectador, sin transigir con ninguna retórica del pictoricismo. Pertenece,

cromático en España. La lección de Rothko», Goya, 184 (1985), pp. 227-238; CaLvo Serraller, Francisco: «La densidad pictórica de Santiago Serrano», El País, Madrid, 15 de junio de 1985.

36. Más adecuado sería decir que la pintura de Serrano se impregnó, hasta cierto punto, de la concepción que de lo abstracto y del espacio interior del cuadro tenía Rothko. En su estudio sobre la influencia de Rothko en la abstracción española de los setenta y ochenta, Javier Hernando afirmaba que Serrano es «el más rothkiano de nuestros pintores», más que Fernando Lerín -en quien quizás también sería muy apreciable el ascendiente de Jules Olitski- y que otros que, como Miguel Ángel Campano o Pancho Ortuño, pudieron asimilar algunos aspectos de la obra de Rothko a través del ejemplo de José Guerrero. Véase: HernANDo CarRasco, Javier: op. cit. pp. $227-238$. 
pues, a esa casta de los artistas radicales, como lo fueron Mondrian, Malevich o, en nuestro tiempo, Rothko, pintor este último con el que lo unen afinidades algo más que fortuitas».37

En el texto del catálogo, Santiago Amón ${ }^{38}$, ferviente defensor en los años setenta del camino abierto por Rothko a otros pintores, declaraba que era «empresa en verdad difícil escribir sobre la obra de Santiago Serrano», y establecía un paralelismo entre su pintura y un texto literario desprovisto de adjetivos, verbos, adverbios y complementos circunstanciales, en el que la indicación de la realidad, inmediata y esencial, una vez excluida cualquier referencia al mundo de las apariencias, se fiaba únicamente a unos cuantos sustantivos entre los que prevalecían dos: extensión y duración ${ }^{39}$.

En lo que respecta al contenido y estructuración de sus imágenes pictóricas, Serrano estableció en su diario que el cuadro no debía comprimir ni aprisionar las formas, ya fuera en conceptos-definición o en límites físicos:

Que las formas se desparramen, no se pueden quedar ahí, tienen que desparramarse.

(...) Trataría ahora de hacer una pintura que no tuviera que estar contenida dentro de un espacio, de manera que fuera ella misma espacio y que por lo tanto, aunque geométricamente tuviera límites, se derramara. Por espacio diría, también, marco, bastidor, cuadro ${ }^{40}$.

Serrano sólo trasladó algunas de sus numerosas cartulinas pequeñas de 1974 y I975, principalmente las que se despegaban de residuos informalistas, a formatos mayores: cartulinas de $40 \times 30 \mathrm{~cm}$. o pinturas sobre lienzo o tabla que llevó en I975 a la exposición colectiva "Reunión Plástica», presentada sucesivamente en el castillo de Peñíscola, el Corral de Comedias de Almagro y la galería Ovidio de Madrid $^{41}$. El artista era consciente de que en el primer semestre de i975 se estaban

37. Moreno Galván, José María: op. cit. pp. 79-80. Moreno Galván puntualizó además que Santiago Serrano no era un geómetra, sino ante todo un pintor: «En la distribución espacialista de Serrano puede aparecer en más de un momento la proporción que los clásicos llamaban «áurea» o «divina». Me parece muy bien que Serrano ni la busque con deliberación ni la eluda con ensañamiento. (...) La geometría marcha por dentro de sus definiciones. La geometría, para decirlo orteguianamente, no forma parte del caudal de sus ideas, sino del de sus creencias». Idem.

38. Santiago Amón defendía con verdadero entusiasmo en la primera mitad de los setenta la inspiración que suponía Rothko para algunos pintores: «Muchas cosas nos han venido de la 'Meca del Arte neoyorkina', pero ninguna, desde luego, tan universal y tan dotada de venturosa actualidad, pese al tiempo transcurrido, como el arte alertador de Rothko. (...) ¿Quién señala el norte o la meta de inclinación de esta nueva visión o revisión del arte de pintar? Rотнко. Fuera ya de tiempo la proclama sistemática de la improvisación y de rutina, son no pocos los pintores españoles que centran en Rothko sus atenciones, y no con ánimo emulador y por la vía del plagio, sino puestos sus cuidados en la nueva mirada que Rothko regaló al universo...» Amón, Santiago: «Atención al abstraccionismo», Gazeta del Arte, Madrid, 28 de diciembre de 1975, p. 3. Amón escribió este combativo artículo en contestación a otro que apenas un mes antes había publicado en la misma revista José María Carrascal —entonces corresponsal en Nueva York- bajo el título «Atención al neorrealismo».

39. Amón, Santiago: «La síntesis suprema de Santiago Serrano», Santiago Serrano, Madrid, galería Ovidio, 1973; y Santiago Serrano, Barcelona, sala de arte Ausias March, El Corte Inglés, 1973, s.p.

40. (ASS), Serrano, Santiago: «Notas» (1973-1994), 2 de diciembre de 1973.

41. En 1975, Serrano expuso una selección de sus obras junto con un grupo de artistas a quienes principalmente unía la amistad: Miguel Navarro, José María Fibla, Jaume Genovart, Peiró Coronado y la artesana de tapices Alicia. De hecho, entre las obras de todos ellos podían observarse más disparidades conceptuales y estilísticas que coincidencias. Todos habían pasado por 'Tres Teresas', residencia de Fibla en Benicarló, a pocos kilómetros de Peñíscola, 
produciendo cambios muy significativos en su obra, relativos no sólo al esqueleto compositivo y a la factura superficial, sino sobre todo a un nuevo estado anímico y espiritual que las imágenes traslucían, con un manejo de la brocha más libre y directo y una progresiva lateralización y orientación vertical de las formas: «De una composición rígida: calmosa y horizontal, o mejor, perpendicular, he pasado a una cierta descomposición de esas estructuras. Todo esto, que quizás haya sido una exigencia anímica, ha hecho que la pintura cambie casi de un modo moral» ${ }^{42}$. El giro entrañaba además otro tipo de acercamiento al cuadro, en el que el espectador no se limitara a ser sujeto pasivo y absorbente de la imagen; antes bien, jugara a completarla mentalmente con las sensaciones y pensamientos que ésta suscitara en él, proyectándose sobre la pintura como lo haría sobre un misterioso espejo ${ }^{43}$.

A partir de 1975 los formatos que maneja Serrano van creciendo cada vez más; las telas de $150 \times 100 \mathrm{~cm}$. ó $225 \times 150 \mathrm{~cm}$. abrirán paso en el período de I976 a I979 a una mayor expansión de las superficies, articuladas con relativa frecuencia en dípticos o polípticos. En la segunda mitad de los setenta Serrano acomete las pinturas de mayores dimensiones de toda su carrera -el Tríptico Propac (I976) alcanza los cuatro metros y medio de largo- si bien en los años noventa, $y$ esporádicamente en la primera década del siglo xxı —véase el Gran Silenciario $(2007)^{44}$-, volverá a trabajar sobre soportes de gran envergadura. Varias pinturas de formato vertical de I975, que enfrentan al espectador a un velo monocromo recamado de pinceladas breves y oblicuas, constituyen el preludio de la obra pictórica de 1976.

\section{PROPAC, 1976: SECAR EL ESPACIO}

I976 es un año clave en la trayectoria de Santiago Serrano, por cuanto representa un estado de madurez, un punto de llegada tras la actividad de los dos años anteriores y a la vez un punto de partida para la producción pictórica que va a ejecutar hasta finales de la década. En I976 realizó una de las pinturas más emblemáticas de toda su carrera, el Tríptico

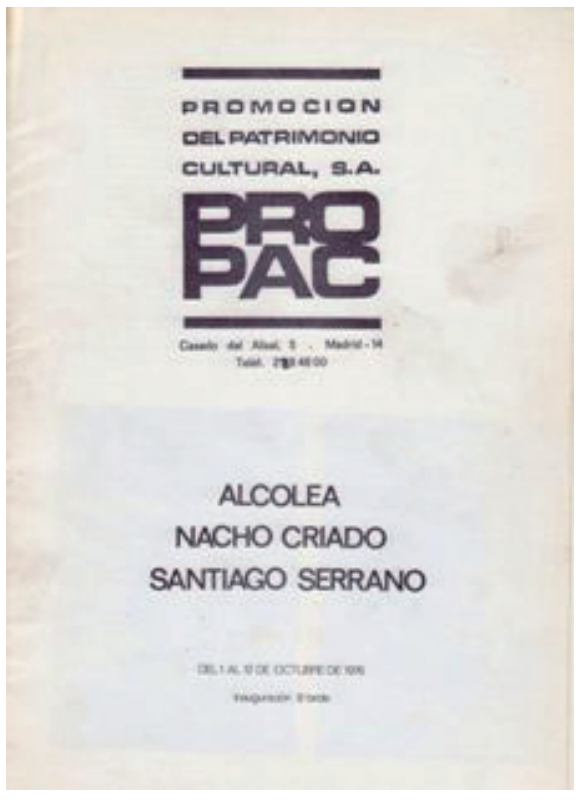

FIGURA 8. PORTADA DEL CATÁLOGO, EXPOSICIÓN «ALCOLEA, NACHO CRIADO, SANTIAGO SERRANO» EN LA SALA PROPAC, 1976.

\footnotetext{
cuyo castillo se les antojó un atractivo e inusual escenario donde realizar un proyecto común en el que convivieran la pintura, los tapices y la música; una muestra cuya única pretensión sería la de brindar un puro disfrute visual y estético a un público distinto del que habitualmente visitaba las galerías de arte. «Reunión Plástica» fue el nombre que dieron a esta experiencia, presentada en el transcurso del año en el castillo de Peñíscola —agosto-, la galería Fúcares - en el contexto del Corral de Comedias de Almagro, en septiembre- y la galería Ovidio de Madrid —octubre. Véase «Experiencias populares», Informaciones de las Artes y las Letras, Madrid, 23 de octubre de 1975, p. 10.

42. (ASS), Serrano, Santiago: «Notas» (1973-1994), 5 de julio de 1975.

43. «El espectador que no espere del cuadro nada que sea ajeno a su ser físico. El cuadro es un agente receptor -incluso podría ser un refugio o una antesala - y como tal está esperando, si cabe, vacío, a que se 'escudriñe en monólogo directo' con él. El espectador no puede exigirle sino por el contrario darle lo que pueda pescar en su soliloquio por los espacios de la obra». (ASS), Serrano, Santiago: «Notas» (1973-1994), 12 de octubre de 1975.

44. Santiago Serrano. Silenciario, Castellón, Fundación Caja Castellón-Bancaja, 2007.
} 
Propac, que formó parte de una curiosa exposición colectiva celebrada en la madrileña sala Propac - Promoción del Patrimonio Cultural, sA ${ }^{45}$ - junto con otras dos obras de Carlos Alcolea y Nacho Criado; una muestra que para una parte de la historiografía y de la crítica ha quedado como uno de los hitos más representativos de lo que fue el arte español en los años setenta del siglo $\mathrm{xx}^{46}$ (FIGURA 8).

Al evocar aquella década, Santiago Serrano no duda en destacar la asiduidad con que él y varios de sus compañeros de generación - principalmente Carlos Alcolea y Nacho Criado- se visitaban e intercambiaban impresiones, opinaban sobre sus respectivos trabajos en marcha y se aportaban ideas y valoraciones mutuamente con espontaneidad y frescura ${ }^{47}$. Nacida del frecuente trato que durante aquella época mantenían los tres artistas, la colectiva de la sala Propac en 1976 fue la única exposición «de grupo» en la que Serrano reconoce haber participado en toda su vida ${ }^{48}$. Ese mismo año, el crítico de arte Eduardo Alaminos escribe el primer comentario minucioso sobre la trayectoria del artista; un análisis que aporta una observación detenida de los rasgos y esquemas formales de la pintura de Serrano, describiendo cómo éstos se habían transformado paulatinamente desde $1970^{49}$.

A finales de 1975 , Serrano había declarado en su diario la voluntad de desarrollar una pintura bajo el lema de «La no evocación. Lo no narrativo» ${ }^{50}$, aún siendo consciente del riesgo de caer en una suerte de «anti-pintura»:

45. Propac (Promoción del Patrimonio Cultural, SA), ubicada en la calle Casado de Alisal, 5 -entre el Museo del Prado y el Parque del Retiro- era una galería que aparte de organizar exposiciones de arte ofrecía servicios de compraventa, tasación, autentificación y restauración de pinturas, alquiler de obras de arte y organización de círculos y conferencias, tal y como rezan los anuncios publicitarios insertados en la prensa española de los setenta.

46. Especialmente convencido de ello está Mariano Navarro: «Nos conocíamos desde antes, pero la primera de las estáticas convulsiones que la pintura de Santiago Serrano habría de producirme, en las casi tres décadas que hemos atravesado juntos, fue en el otoño de 1976 cuando participó en una exposición colectiva, que supimos entonces, y hoy tenemos la más absoluta certeza, de que era trascendente para el sentido de una época, me refiero a Alcolea, Nacho Criado y Santiago Serrano, que tuvo lugar en la sala PROPAC, Promoción del Patrimonio Cultural SA». NAvarro, Mariano: «Egam cumple 35 años / Santiago Serrano. De los nombres del cuadro», Siete lustros de la galería Egam, Madrid, Egam, 2004, pp. 23-25.

47. El grupo de amigos - o «la panda», tal y como lo denomina coloquialmente Serrano y como aparece reiteradas veces en sus dietarios de aquella época-, estaba compuesto por Julia Varela y Fernando Álvarez-Uría, Carlos Alcolea, Baldomero Concejo, Nacho Criado y su esposa Isabel Malpica, Juan Hidalgo, Santiago Serrano y María Carballido. Javier Utray, que vivía cerca de Alcolea, no frecuentaba tanto estas tertulias y tuvo menos relación con Santiago Serrano. En algún momento se unieron al grupo el crítico Eduardo Alaminos y su esposa Ana. Serrano puso a disposición de Juan Hidalgo y Nacho Criado su estudio de la calle Roma para que ambos realizaran algunos de sus videos-performance, y ejerció de reportero visual del proceso de puesta en escena y grabación.

48. No obstante, la consideración de esta muestra de la sala Propac como un trabajo «de grupo» no deja de resultar problemática, máxime cuando las tres obras que la componían evidenciaban notorias diferencias en cuanto al estilo y al mundo personal que en ellas se cifraba. La exposición constaba de un núcleo de tres obras, una por cada artista participante: Schreber also escribe (Carlos Alcolea), Vertebr/Andalus (Nacho Criado), y Tríptico (Santiago Serrano), más una serie de documentos: por parte de Alcolea, fotografías de Nueva York y de obras de Beuys en la René Block Gallery; Criado incluyó fotos de acciones y un esquema de Vertebr/Andalus compuesto de fotografías del campo andaluz; Serrano, una reproducción a gran tamaño de una de las páginas del Cuaderno 1971-1973. La colectiva que se celebró en 1977 en la Caja de Ahorros de Alicante y Murcia, coordinada por el crítico Mariano Navarro, profundizaba en el planteamiento de Propac y ampliaba la selección de artistas participantes -Eva Lootz, Miguel Navarro, Juan Navarro Baldeweg, Javier Utray, Isidoro Valcárcel Medina-, entre los que volvían a figurar Santiago Serrano, Carlos Alcolea y Nacho Criado; los dos primeros, con las mismas pinturas que habían llevado a la sala de Propac un año antes. Véase Navarro, Mariano: «Los setenta de Nacho Criado», Artecontexto, 34-35 (2012), pp. 121-129.

49. Alaminos, Eduardo: «Santiago Serrano: Del cuadro a la superficie», Artes Plásticas, Barcelona, diciembre de 1976, n. $^{\circ} 13$, pp. $83-87$.

50. (ASS), Serrano, Santiago: «Notas» (1973-1994), diciembre de 1975. 
La manifestación o el mensaje inmediato de la obra de arte en plan narrativo no me interesa (...), en tanto lo que de misterio puede tener queda sacrificado en aras de la inmediata captación. Es así que me planteo una pintura exenta de armas narrativas o incluso evocativas. La no evocación quizás en una obra de arte sea «de entrada» una utopía, pero al referirme a no evocación quisiera decir, más que caer en lo imposible o en el absurdo, dejar atrás lo inmediatamente evocador y de esta manera conseguir mediante el ejercicio plástico PINTAR una nueva realidad plástica. Tampoco huyo absolutamente de la no evocación, quiero decir, que el hecho de que por la textura, las dimensiones posiblemente del espacio, el color, etc., pueda haber referencias hacia cosas concretas, no por eso voy a huir de tales sustancialidades, pero tampoco las voy a admitir como tales, porque el propósito, en definitiva, sería el contrario. La búsqueda de esa realidad no me obligaría - de momento- a buscar una

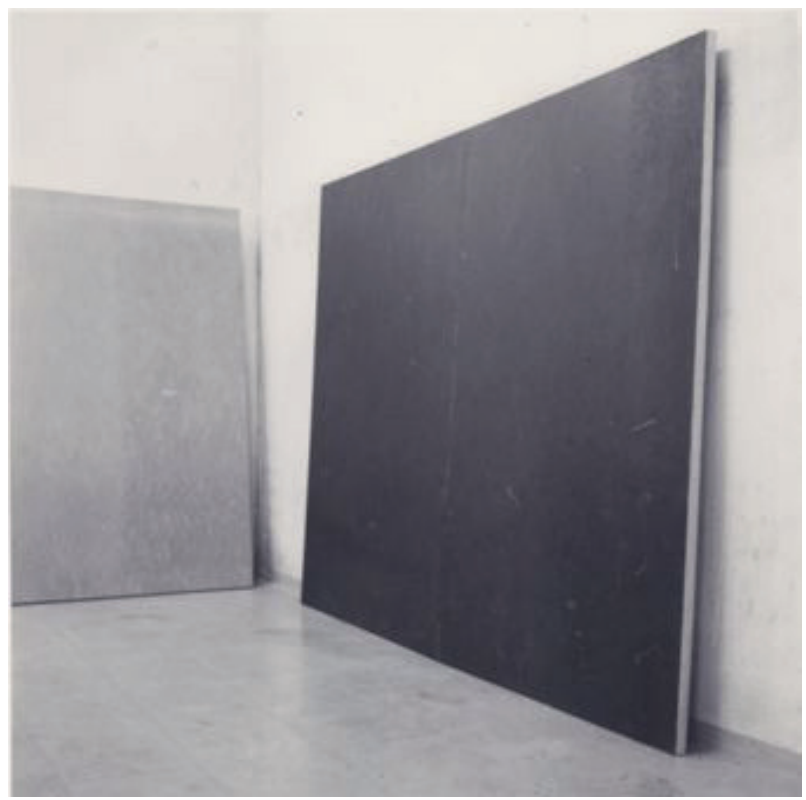

FIGURA 9

DETALLE DEL TALLER DE SANTIAGO SERRANO EN 1976-1977 Archivo del artista. plasticidad a nivel de superficie pictórica, sino a precipitar más los medios - todos los míos-y acercarme al filo incluso de lo absurdo, lo anti. El color está formando en este momento una alianza con esa realidad; el tratar de conseguir, única y exclusivamente, grises ópticos, me lleva ya a una ficción pictórica, a una sensación misteriosa del color, que según el tratamiento hace por sí mismo un mundo aparente de ensoñación y de mística51 (FIGURA 9).

Serrano bautiza el nuevo concepto espacial que sustentará su pintura con el lema «Secar el espacio», que unirá a otro concepto, «ósmosis», procedente de la biología celular, que tres años antes ya había utilizado para nombrar una serie de cuadros abocetados en el Cuaderno I97I-I973. Metafóricamente, la pintura reproduciría la ósmosis que constantemente se produce en nuestro interior a un nivel celular; un proceso necesario para mantener nuestro organismo en constante equilibrio. La

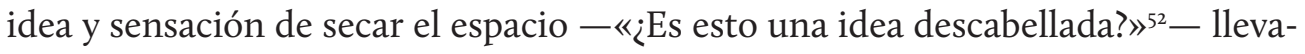
ría a Serrano a eliminar cualquier elemento que pudiera ser vehículo de indicios naturalistas ${ }^{53}$, precisando aún más el significado de tan peregrina intuición:

51. Idem. La elipsis, o la total omisión de las evocaciones naturalistas o literarias, era un trayecto árido y duro que Serrano había emprendido años atrás, tal y como había observado el crítico Santiago Amón en su comentario sobre la obra expuesta en la galería Ovidio en 1973. "Santiago Serrano ha llevado la realidad al límite último de la evocación. Un grado más acá, y nos sería factible la sumaria inserción de una anécdota; un grado más allá, y todo pararía en disolución sin memoria posible». Amón, Santiago: op. cit.

52. (ASS), Serrano, Santiago: «Notas» (1973-1994), 19 de enero de 1976.

53. «Una sensación, secar el espacio. ¿Parar el tiempo? ¿Existe el espacio húmedo, frío, seco, empapado, oloroso, ruidoso, gris, anaranjado, violáceo o blanco? (...) Con todo lo anteriormente dicho no excluyo nada, pero tampoco quiero para mi obra alientos sobradamente naturalistas y de otras especies; no me interesa el bello color 
Las formas integradas en el espacio todo, los espacios con los espacios, diferenciados, sí, pero hermanados, integrados. (...) El espacio atraería hacia sí, envolvería, traspasaría como un problema osmótico. De otra manera, un espacio no excluiría a otro espacio sino que lo acogería, lo arroparía y le daría toda su inmensidad para, sin perder todas sus características particulares, convertirse en uno ${ }^{54}$.

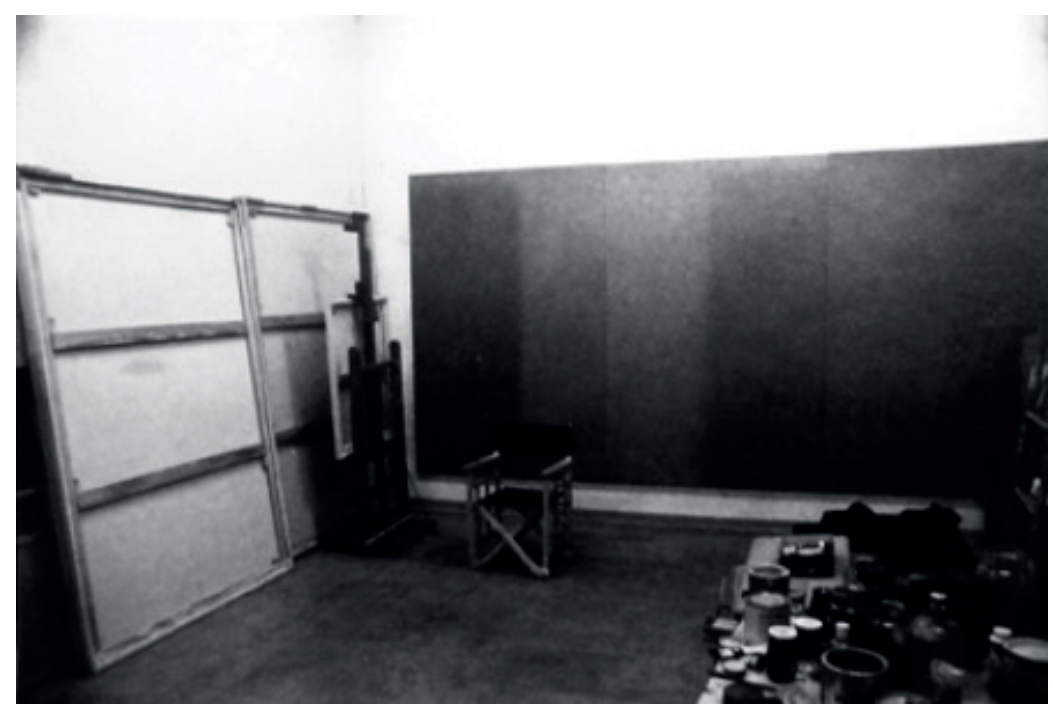

FIGURA 10.- FOTOGRAFÍA DEL TRÍPTICO EN EL TALLER DE SANTIAGO SERRANO, 1976 Archivo del artista.

\section{EL TRÍPTICO55}

En esta pintura de gran formato, cuya génesis menciona el pintor en su diario, se condensa inmejorablemente la práctica pictórica de Santiago Serrano durante $1976^{5^{5}}$. Mediante un tratamiento basado en pinceladas cortas y verticales, grises ópticos, alternancia de juegos monocromáticos y rozaduras de pincel duro que más que manchar el lienzo depositan levemente su carga, Serrano buscó plasmar una «realidad elemental» ${ }^{57}$; pintar un cuadro que ante todo mos-

trara su propia piel y no descubriera nada más allá de la inmediata realidad de su superficie (FIGURA IO). Al no existir en la pintura otros datos distintos a los de su propia epidermis, el cuadro se constituye en «un objeto adimensional, no concéntrico, dispersivo ${ }^{58}$ que fuerza al espectador a buscar referencias y asideros familiares en el exterior de su perímetro.

Serrano apuntó lo indefinible del «motivo» o asunto de la pintura, que llegaba a convertirse en un puro hálito:

de la paja a la luz de la luna, ni la repercusión del trino del gorrión ni el canto del grillo, ni la cegadora semblanza del crepúsculo, por ejemplo». (ASS), SerRANO, Santiago: «Notas» (1973-1994), diciembre de 1975.

54. (ASS), Serrano, Santiago: «Notas» (1973-1994), 22 de enero de 1976. Este concepto espacial Ilevaba aparejada una particular consideración del factor tiempo, de modo que la imagen pictórica debía reflejar un peculiar estado de intemporalidad, sugerido por términos como: «parar el tiempo», «fuera del tiempo», «fuera del tiempo del tiempo», «extraído del tiempo» o «La solidificación del tiempo». (ASS), SerRANO, Santiago: «Notas» (1973-1994), 3 de junio de 1976.

55. Esta obra ingresó en la colección del MNCARS en marzo de 2001.

56. «Comencé hace tres semanas un tríptico de $225 \times 450 \mathrm{~cm}$. Lo que decía el tres de junio lo estoy materializando en él; quizás el problema de las medidas, cuadro metros y medio, suponga un esfuerzo más en todos los sentidos, pero lo que veo más es la terrible importancia que tiene el ejercicio pictórico sin trucos». (ASS), SERRANO, Santiago: «Notas» (1973-1994), 25 de junio de 1976.

57. (ASS), Serrano, Santiago: «Notas» (1973-1994), 4 de julio de 1976

58. Idem. 
Quiero hacer una pintura dispersiva donde la dimensión de la obra - superficie- se salga de la medida de la visión cotidiana. (...) Que el «motivo» no pueda encerrarse en la obra, que «eso» se escape, no pueda estar comprimido, buscar el «aliento» que no pueda ser «encerrado» en un lienzo 59 .

La materialidad de la obra era el fruto de un proceso netamente acumulativo en el que se ponían en juego la textura de la tela, la imprimación y el óleo (pigmento y aceite) ${ }^{60}$; un procedimiento sedimentario y metódico por el cual se concentraba el pintor únicamente en el acto de pintar, situado en posición frontal ante el lienzo; una colocación que no era fortuita, sino «consecuencia de una situación ante la vida ${ }^{61}$, y que por lo tanto obedecía a una determinada actitud.

Serrano concibió el color-luz como objeto de una investigación y búsqueda, un «elemento irreal y huidizo» como «el sol a través del humo» o un «baño de grises ópticos $»^{62}$. La pintura adquiere la condición de un maquillaje que crece mediante la lenta y meticulosa superposición de estratos de distintas densidades, con pinceladas pequeñas y reiteradas que hacen de la superficie un campo aglomerado y compacto:

El resultado final era la acumulación de capas de pintura, estratos, etapas, por un proceso gestual de afirmación, (...) por la reiterada labor consciente, concentrada y ejercida de la voluntad-poder ${ }^{63}$ para dejar unas capas sucesivas de máscaras, formando en su proceso la máscara final ${ }^{64}$.

59. Idem. Estas reflexiones reanudan y perfeccionan aquellas que el pintor se había hecho en 1973, aludiendo a la voluntad de que las formas no quedaran encerradas ni comprimidas en el encuadre, expandiéndose libremente.

6o. Serrano escribió una concisa descripción de los elementos materiales del Tríptico, que había pintado sobre tela de algodón: «He pintado anteriormente sobre soportes distintos, madera, papel y tela de lino; la utilización de la tela de algodón vendría dada por la economía, por su calidad a la hora de imprimirla. La tela de algodón da un carácter menos duro a la pintura, su superficie es más regular y tiene una flexibilidad distinta a las otras telas, como son el cáñamo y el lino. La imprimación de este soporte sería una preparación de sulfato de cal y óxido de zinc; esta preparación, aparte de ser absorbente, forma una pequeña granulosidad (sic) idónea para que no existan brillos excesivos». (ASS), Serrano, Santiago: «Notas» (1973-1994), 10 de diciembre de 1976.

61. (ASS), Serrano, Santiago: «Notas» (1973-1994), 1976.

62. Idem.

63. Acerca de esta idea, Serrano insiste: «Ante una mancha, ante una superficie, ante un gesto, ante un toque, ante un color. La fuerza, el poder de ejercer la voluntad reiterada, la capacidad de transformar, la autonomía de la voluntad. Voluntad y poder. Despertar de la conciencia. Conciencia del acto. Actuación volitiva». Idem.

64. (ASS), Serrano, Santiago: «Notas» (1973-1994), diciembre de 1976. El pintor resumió magníficamente el sentido de su trabajo pictórico de 1976 y 1977 en un párrafo que, con pequeñas modificaciones, insertaría Juan Antonio Aguirre en su texto de presentación para el catálogo de la exposición individual de Serrano en el Museo Español de Arte Contemporáneo (1981): «La pintura enmascara el cuadro. La pintura maquilla el cuadro, lo utiliza y lo hace espejo de ella misma. Este maquillaje es depositado lentamente y con precisión, se reparte por el cuadro con mayor o menor difusión. Aquí la pintura (el camuflage, el maquillaje) se va depositando, almacenando con economía, con orden, lenta y osmóticamente, hasta formar un estrato, un nivel con una densidad determinada, que sumado consecutivamente a otro proceso osmótico/pictórico hará en definitiva formar una máscara. El cuadro se oculta a sí mismo, se mimetiza, se integra, se define, finge ser, aparenta. La ósmosis color-materia baña el cuadro, se deposita sobre él. El color no define nada ni se define a sí mismo, es materia. El color-materia no evoca, no relata; especifica». (ASS), Serrano, Santiago: «Notas» (1973-1994), 26 de julio de 1977. En el encabezamiento del manuscrito, Serrano escribió, con subrayado: «Escrito para la revista DATA». 


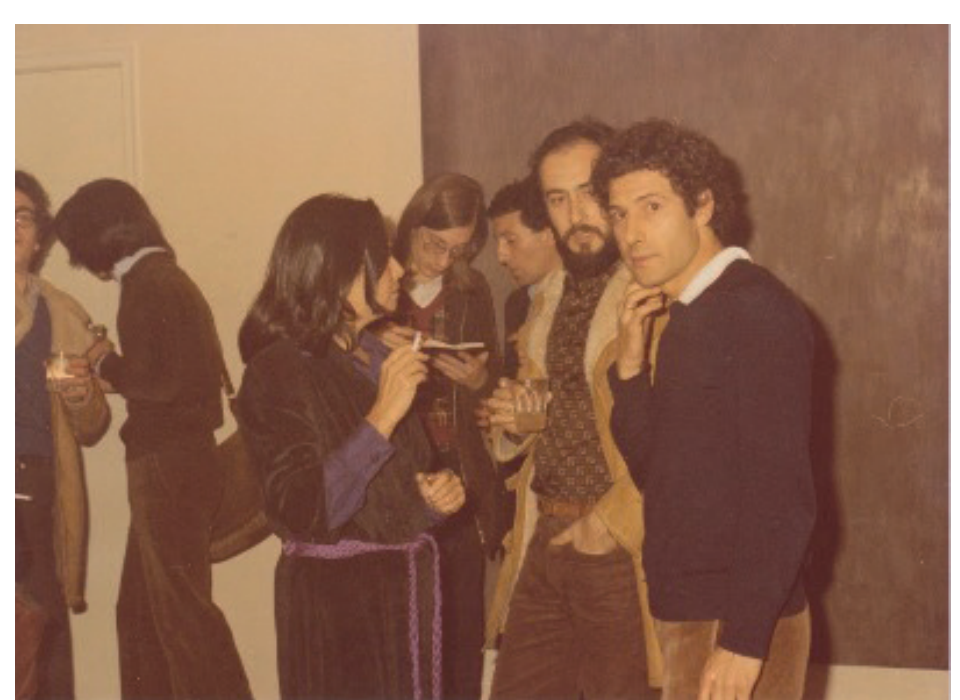

FIGURA 11. INAUGURACIÓN DE LA EXPOSICIÓN «SANTIAGO SERRANO» EN LA GALERÍA AELE, 1977.

De derecha a izquierda: Santiago Serrano, José Luis Fajardo, Javier Utray, Mariano Navarro, Carmen Waugh - directora de la galería en aquel momento-, Nacho Criado y Chema Cobo. Archivo del artista.

\section{SISTEMA DEL NO COLOR O COLOR ANTISISTEMA}

A finales de abril de 1977, Santiago Serrano presentó una decena de cuadros en una exposición individual en la galería Aele (Madrid): cinco de I50 $\times 100 \mathrm{~cm}$., tres de $225 \times 150 \mathrm{~cm}$., y dos dípticos de $225 \times 300 \mathrm{~cm}$. y I50 $\times 200 \mathrm{~cm}^{65}$ (FIGURA II). El conjunto reflejaba la búsqueda de una proporcionalidad y armonía en los tamaños mediante agrupaciones de soportes con medidas iguales, $y$ ofrecía la lectura unitaria de un trabajo realizado sin solución de continuidad, dotado de un tratamiento pictórico similar en todas las piezas del discurso. A la vista de la exposición, Santiago Amón creía que sólo aparentemente podía asociarse la obra de Serrano a las corrientes del neo-abstraccionismo impulsadas en Francia por el crítico Marcelin Pleynet y a las propuestas teóricas de los pintores vinculados a Supports/Surfaces y a la revista Peinture, como Louis Cane o Marc Devade ${ }^{66}$ (FIGURA I2).

No obstante, parece ineludible confrontar la pintura de Santiago Serrano en los setenta con la producción de los integrantes de Supports/Surfaces, quienes propusieron una suerte de reinvención de la pintura, una crítica y desmenuzamiento sistemático de los elementos e ingredientes de este arte, junto con una reivindicación del gusto por el acto de pintar, en cuya base práctica se evidenciaba la influencia de la abstracción norteamericana de los años cincuenta y sesenta. Con posiciones que variaban según la individualidad de cada miembro - Arnal, Bioulès, Cane, Devade, Dezeuze, Dolla, Grand, Pagès, Pincemin, Saytour, Valensi, Viallat—, Supports/Surfaces impulsó entre 1970 y $1972^{67}$ un análisis de las entrañas de la pintura desde una

65. Coincidiendo con la exposición individual de Santiago Serrano en la galería Aele (Madrid), inaugurada a finales de abril de 1977, se abría en el Palacio de Cristal del madrileño Parque del Retiro la exposición colectiva «En la pintura», en la que participaban varios de los artistas integrantes del grupo de Trama - José Manuel Broto, Gonzalo Tena, Javier Rubio, Xavier Grau-, más otros que, no perteneciendo al grupo aragonés, habían sido invitados en aquella ocasión - Pancho Ortuño, Carlos León y Gerardo Delgado. Asimismo, por aquellas mismas fechas se presentaba una exposición individual de Pancho Ortuño en la galería Juana Mordó y otra de Gonzalo Tena en la galería Buades.

66. Amón, Santiago: «Santiago Serrano», El País, Madrid, 7 de abril de 1977, p. 17.

67. La denominación Supports/Surfaces data de 1970; fue propuesta por Vincent Bioulès como título de una exposición colectiva en el ARC de París, que convocaba a Dezeuze, Saytour, Valensi, Viallat, Devade y a él mismo. 1971 fue el año de apogeo de Supports/Surfaces — con dos grandes exposiciones, en la Cité Universitaire de París y en el Théâtre municipal de Niza-, a la vez que el año de su fragmentación. Aquel año, Cane, Devade, Dezeuze y Bioulès lanzaron la revista Peinture, cahiers théoriques, que apareció como una emanación de Tel quel en el campo de las artes plásticas y que se haría eco de las polémicas en torno al grupo. Dos exposiciones aún tuvieron lugar en 
óptica materialista-marxista cargada de implicaciones políticas, a la que se adhirieron más tarde los pintores españoles que fundaron el grupo de Trama (I973-I978): José Manuel Broto, Javier Rubio, Gonzalo Tena y Xavier Grau ${ }^{68}$.

Entre 1978 y I980, cuando los integrantes de Trama se alejaban de la práctica pictórica o tomaban cada uno por su lado otras direcciones completamente distintas, Serrano todavía continuó enfrascado en un trabajo pictórico dotado de un altísimo y radical grado de abstracción, que Juan Antonio Aguirre encuadraría bajo el lema «pintar la pintura». El crítico de arte Francisco Rivas, en su reseña crítica a la segunda exposición individual de Serrano en la galería Aele (I979), advirtió esta particular y rigurosa persistencia del artista en el camino que se había trazado desde el mismo inicio de aquella década: «Cuando gran parte de los que en años pasados se embarcaron en la ortodoxia de la pintura-pin-

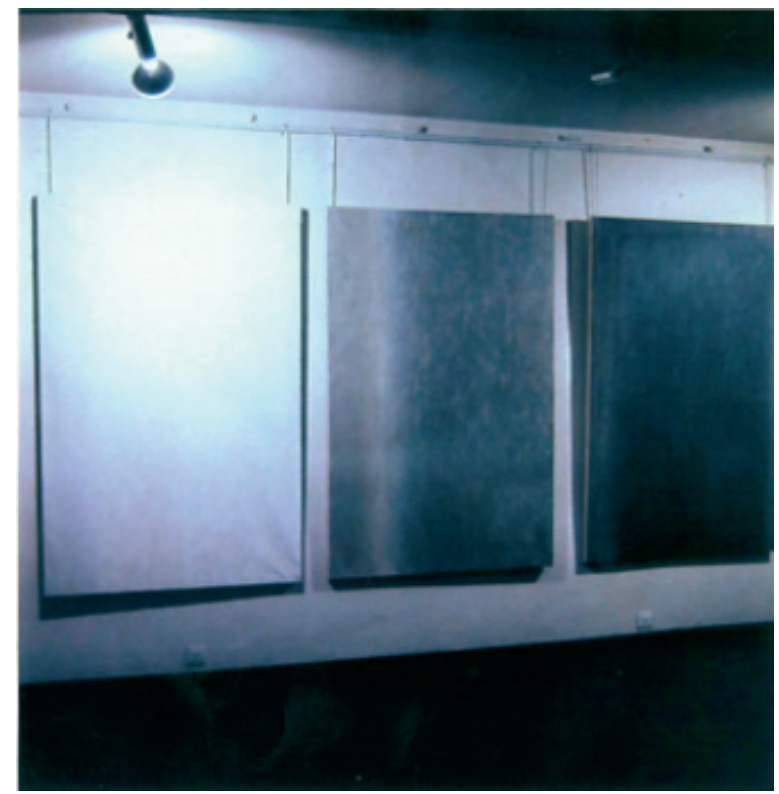

FIGURA 12. DETALLE DE LA EXPOSICIÓN INDIVIDUAL DE SANTIAGO SERRANO EN LA GALERÍA AELE, 1977 Archivo del artista. tura están dando marcha atrás, él sigue, dale que dale, se diría que más ortodoxo que nunca» ${ }^{69}$.

Cierto es que Santiago Serrano conocía bien durante los setenta la obra pictórica y teórica del grupo Supports/Surfaces ${ }^{70}$; aunque desde luego, en su primer viaje a París (I968) no accedió todavía a ningún tipo de información sobre las actividades de quienes lo integrarían. Aquel discurso ideológico derivado del materialismo histórico, el freudomarxismo y el maoísmo, que envolvía la pintura del grupo francés y de su correlato español, Trama, no interesó demasiado a Serrano ni fue acicate de su trabajo pictórico, a pesar de que algunos de los textos críticos que en los setenta se escribieron sobre su pintura, concretamente los debidos a Eduardo Alaminos, analizaban su obra desde un enfoque materialista que establecía la condición

1972 bajo la etiqueta de Supports/Surfaces, en Estrasburgo y en Montpellier. Véase ToMA, Kathy y SEMIN, Didier: «Cronología (1968-1977)», en Los años Supports Surfaces en las colecciones del Centre Georges Pompidou (catálogo de la exposición), París, Centre Georges Pompidou, Musée National d’Art Moderne / Madrid, Centro Cultural Conde Duque, 1998, pp. 153-178.

68. Trama no era un colectivo exclusivo de pintores y de pintura, sino que había nacido, en palabras de Javier Lacruz, como «un grupo de intervención simultánea en varios campos de la acción revolucionaria (política, pintura, crítica, ensayo, poesía, literatura, psicoanálisis, pensamiento...) que se adhiere al novedoso discurso francés; el mismo que ampara al grupo Supports/Surfaces formado por Cane, Devade, Dezeuze, Viallat, etc., cuyo trabajo se basa en el análisis de los aspectos materiales del cuadro: el soporte y la superficie (la tela y el bastidor). Fuentes teóricas comunes, pero prácticas absolutamente dispares, dada la deconstrucción de los componentes del cuadro de unos y la defensa a ultranza de su integridad por otros. Es decir, de la pintura en su valor tautológico: la pintura-pintura». Véase la página web del psiquiatra, psicoanalista, coleccionista y estudioso de arte Javier Lacruz Navas, www.javierlacruz.es; asimismo, su libro El grupo de Trama (2 vol.). Zaragoza, Mira editores, 2002-2003.

69. Rivas, Francisco: «Santiago Serrano», El País, Madrid, 17 de mayo de 1979.

70. Serrano conserva algún ejemplar de la revista Peinture. Cahiers Théoriques de aquella época. 
funcional de la producción pictórica como parte integrante de un complejo engranaje socioeconómico ${ }^{71}$.

Más que las coincidencias formales que fácilmente pueden apreciarse entre algunas obras de Santiago Serrano - no sólo de los setenta, sino también posteriores-y obras pertenecientes a pintores que formaron parte de Supports/Surfaces - como Vincent Bioulès, Louis Cane y Marc Devade-, interesaría reconocer una afinidad esencial entre el afán que caracteriza al grupo francés por analizar y desmontar los elementos constitutivos de la pintura, y el empeño que Serrano manifiesta en los setenta por emprender su particular estudio y análisis de cada uno de los elementos materiales que componen este arte - visible en el esbozo de una teoría de la pintura que registró en su diario «Notas» ${ }^{72}$. Algunas de las ideas sobre la pintura tal y como la entendía Supports/Surfaces, reunidas por Claude Viallat a finales de los sesenta ${ }^{73}$, serían equiparables a los principios teórico-prácticos que orientaban el trabajo de Santiago Serrano, tales como el enfoque de la pintura como una especie de topología y topografía; el análisis concienzudo de los materiales empleados, con el fin de que la imagen resultante se subordine al trabajo sobre el material y no al revés - lo cual coincide con una de las afirmaciones más reiteradas de Serrano: «La materia te define»; el desmenuzamiento de los componentes tradicionales de la pintura y el trabajo específico sobre cada elemento por separado.

También le acercaría en cierta medida a la concepción que de la pintura tenía Supports/Surfaces el empeño, aún más difícil y problemático, de alejarse radicalmente de cualquier vestigio narrativo o evocativo. De acuerdo con esta pretensión, el objeto de la pintura debía ser la propia pintura, y los cuadros expuestos sólo estarían referidos a ellos mismos, sin apelar a nada «exterior» como la personalidad del artista, su biografía o la tradición - la historia del arte. En el cumplimiento de tales propósitos, sin embargo, Serrano debió de hallar mucha mayor inspiración y mejores referencias en Rothko, en otras figuras de la abstracción norteamericana, como Barnett Newman o Richard Diebenkorn, y en la técnica de otros maestros más lejanos en el tiempo como Bonnard, Velázquez y Tiziano.

Las semejanzas de estrategia formal que pueden observarse entre obras concretas de Serrano y obras de artistas como Vincent Bioulès o Louis Cane, no son tan definitorias ni tan fundamentales como para afirmar que Santiago Serrano siguiera de cerca los pasos de aquellos pintores franceses. De hecho, en sus diarios no existe referencia alguna a Supports/Surfaces, excepto cuando menciona el hecho de que algunos críticos han relacionado tardíamente su trabajo con aquellos artistas a raíz de su exposición individual en la galería Aele en $1977^{74}$. En cambio, Serrano se tomó la molestia de reproducir a mano en su diario un texto de I973 del pintor Claudio Verna ${ }^{75}$, uno de los artistas que, junto con Carmen Gloria Morales

71. Alaminos, Eduardo: «En los espacios de la pintura», Santiago Serrano: 1977, Madrid, galería Aele, 1977, s.p.

72. (ASS), Serrano, Santiago: «Notas», 1973-1994, septiembre de 1976.

73. Véase SEMIN, D.: «El caldero», en Los años Supports Surfaces en las colecciones del Centre Georges Pompidou (catálogo de la exposición), París, Centre Georges Pompidou, Musée National d’Art Moderne / Madrid, Centro Cultural Conde Duque, 1998, pp. 17-21.

74. (ASS), Serrano, Santiago: «Notas» (1973-1994), 15 de mayo de 1977.

75. Verna (Guardiagrele -Chieti-, 1937) proponía una definición del arte pictórico con la que Serrano debió de 
-amiga de Serrano-, Claudio Olivieri, Gianfranco Zappettini, Pino Pinelli, etc., protagonizó la abstracción italiana de los setenta ${ }^{76}$. Es bastante probable que Serrano prestara incluso más atención a lo que ocurría en Italia que a lo que sucedía en Francia, dado que durante aquella década estuvo suscrito a la editorial italiana Giancarlo Politi editore, por cuyo directorio había localizado y conocido a Carmen Gloria Morales ${ }^{77}$. De hecho, Serrano cuenta en su fondo bibliográfico personal con varias publicaciones en cuya primera página firmó y anotó el lugar y la fecha de su adquisición —《Milán, julio de I977»-: catálogos de exposiciones individuales de Carmen Gloria Morales, Noël Dolla — artista que participó en Supports/Surfaces-, Claudio Verna, y de algunas colectivas italianas como «La contradizione del segno» ${ }^{8}$.

En 1978 Serrano realizó una de las obras estelares de su producción, el díptico $L a$ bisagra, perteneciente hoy en día a la colección Helga de Alvear, así como un conjunto de acuarelas sobre cartulinas, algunas de ellas trípticos, agrupadas en bellísimas y pulcras series: De la luz, Del gris y el amarillo y Serie abierta. Serrano pretendía ir más allá en su empeño de modificar la percepción del espectador y de alterar los fundamentos cromáticos de la pintura tradicional, a través de conceptos tales como «sistema del no color», «color antisistema», «color como no prejuicio» o «color no percibido». Comentando un cuadro que había pintado en I977, con relación a otro sobre el que estaba trabajando en I978, el artista manifestó su interés en plasmar una incesante y sutil interpenetración entre los elementos constitutivos de la pintura, una suerte de ósmosis entre las diversas imprimaciones, toques de pincel, capas de pintura y franjas verticales que articulaban la imagen:

identificarse plenamente, hasta el punto de traducirla al español en una cuartilla: «Abordar la pintura hoy significa, antes de nada, liberarla de sus atributos 'tradicionales', a saber, las significaciones simbólicas, autobiográficas, literarias y metafóricas. Eso significa reinventarla, objetivarla, alejarla de sí (...)». Texto manuscrito de Santiago Serrano en una cuartilla suelta, sin fecha, anexa a su diario Notas (1973-1994), ASs. El texto original de Claudio Verna en italiano puede consultarse en CerritelLI, C.: // Corpo della pittura. Critici e nuovi pittori in Italia 1972-1976. Torino, Martano Editore, 1985, pp. 100-102.

76. Véase Pittura 70. Pittura Pittura e Astrazione Analitica (catálogo de la exposición), Milán, Fondazione Zappettini, 2004

77. Serrano recuerda bien que se encontró por primera vez con Carmen Gloria Morales en el mismo viaje a Italia en que conoció a Juan Hidalgo, miembro del grupo Zaj. Esto sucedió necesariamente en 1974 o 1975, dado que en 1976 ya hay constancia, gracias a los dietarios del artista, de la relación de amistad que hubo entre Serrano e Hidalgo en Madrid. Serrano había visto reproducidas en catálogos o revistas varias pinturas de Carmen Gloria Morales, reveladoras de un sentido de pureza y esencialidad con el que se identificaba completamente. Decidido a conocerla en persona, la localizó en Milán gracias a un directorio de Giancarlo Politi Editore, editorial que publicaba monografías de artistas y la revista Data. Carmen Gloria Morales había nacido en Chile el mismo año que Santiago Serrano, 1942, y se había formado como pintora en Italia, donde vivía desde los años cincuenta. En su época de estudiante de arte pudo conocer la obra de Lucio Fontana y Piero Manzoni, y ya en los sesenta, cuando se trasladó a Roma, la pintura de tendencia monocromática de Francesco Lo Savio, aparte de una gran exposición de Rothko celebrada en 1962 en la Galeria Nazionale d'Arte. En 1971 produjo su primera pintura en el formato sobre el que tantas veces trabajaría en lo sucesivo: un díptico formado por dos paneles de idénticas dimensiones y separados por escasos centímetros. El panel de la izquierda, pintado con un severo registro monocromo; el de la izquierda, un lienzo en blanco. Véase AcCAme, G.M.: Carmengloria Morales: Presenza e Totalità, Pierluigi Lubrina Editore, 1991 y «Carmengloria Morales: painting as concept and action», Unique Act. Five abstract painters: Frederic Matys Thursz, Sean Scully, Carmengloria Morales, Seán Shanahan, Ruth Root (catálogo de la exposición), Dublín, Dublin City Gallery The Hugh Lane, 2008.

78. Exposición celebrada en la Sala delle Colonne, Turín, marzo-abril de 1977, que reunía obras de Luciano Bartolini, Enzo Bersezio, Enzo Cacciola, Marcello Camorani, Mimmo Conenna, Mario Daniele, Marcello Landi, Sandro Martini, Vittorio Matino, Carmen Gloria Morales, Christian Parisot, Antonio Giovanni Pintori y Giorgio Zucchini. 
El cuadro tenía una división vertical que lo partía en dos partes, una de ellas con preparación verde pálido, más o menos; la otra, rojizo pálido, más o menos; el ejercicio, la experiencia, era confundir las dos masas. En la verde, meter rojo, trasluciendo la base, y en el rojo meter verde trasluciendo la base; $y$ vuelta a empezar hasta sofocar el color de ambas partes. En este cuadro propongo, con una base $x$, alterar el cromatismo más íntimo de la pintura, comenzar a pintar con un color determinado, dada una escala, y acabar con el último color de esa escala; de tal manera que proporcionaría el placer de ver un desarrollo inarmónico, anárquico, no regido por las leyes pictóricas; la anulación sistemática - progresiva - de las capas de color, para sacar una definición personal de un color, una relación personal pictórica. El resultado final sería el último color como maquillaje «cuasi-final» del proceso ${ }^{79}$.

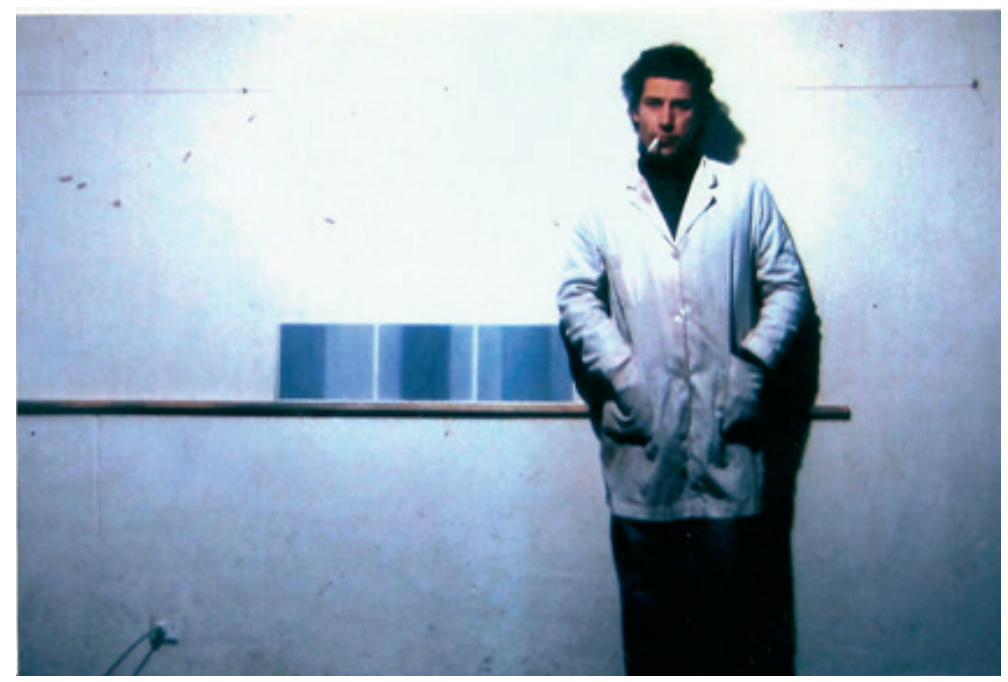

FIGURA 13. SANTIAGO SERRANO EN SU ESTUDIO, CA. 1977-1979 Archivo del artista.

\section{UNA PINTURA HUIDIZA}

De cara a su exposición individual en la galería Fúcares (I979), Serrano realizó trípticos de acuarela sobre papel, dividiendo la superficie en franjas verticales $u$ horizontales y superponiendo aguadas consecutivas ${ }^{80}$ (FIGURA I3). El pintor buscaba materializar el valor de una exactitud compositiva matemática y fría, iluminada por un color «que no defina nada externo a sí mismo» ${ }^{8 \mathrm{I}}$. Por otra parte, las obras traslucían un cierto estado anímico del artista reflejado en su afirmación, escrita por aquellas mismas fechas en su diario, de que «hay que diluirse, diluido, diluyente». Este

79. (ASS), Serrano, Santiago: «Notas» (1973-1994), 30 de septiembre de 1978. Serrano precisaba aún más, con un ejemplo práctico, en qué consistía aquel raro planteamiento cromático: «Dentro del proceso, seguiría la alteración interna del cuadro dividido en franjas, espacios, lugares. A saber: en un cuadro de $100 \times 100$ dividiría el espacio en 3 franjas o 4, verticales u horizontales, y comenzando por la escala de color que eligiera, por ejemplo: azul, rojo, naranja, amarillo, verde; en la primera franja izquierda esta escala sería válida; está la 2. a alteración del orden: rojo, azul, naranja, amarillo, verde; $3 .^{\circ}$ azul, naranja, rojo, verde, amarillo, y así estudiar estas descomposiciones». (ASS), SerRano, Santiago: «Notas» (1973-1994), 1 de octubre de 1978.

80. Varias de las composiciones que Josef Albers recoge en las láminas didácticas de su libro La interacción del color - o también los ejercicios que denomina «yuxtaposición restringida» con bandas verticales de coloresaparecen en la pintura de Santiago Serrano, si bien éste se aleja de aquel concepto de pletina cromática uniforme, apta para plantear ejercicios demostrativos de las propiedades y leyes del color, como los que propone Albers en su tratado. Serrano, en cambio, «cocina» los colores tornándolos inciertos y misteriosos, enriquecidos con infinitos matices tonales y lumínicos, a menudo envueltos en atmósferas que prestan a la imagen una paradójica conjunción de firmeza arquitectónica y disolución formal. Véase ALBERS, Josef: La interacción del color. Madrid, Alianza Forma, 1985.

81. «Planteamientos atmosféricos, fríos, distantes, no definibles. Planteamiento molecular, lumínico, LUz del color. El color como luz, como luces, chorros de luz, columnas de luz. El color puede ser el medio, aquí no sería el fin, igual que no lo es la tinta para el poeta». (ASS), SERRANO, Santiago: «Notas» (1973-1994), 10 de diciembre de 1978. 
«planteamiento pictórico molecular», desplegado en dípticos y polípticos alargados, con superficies segmentadas en amplias bandas verticales que van del gris azulado, violáceo o verdoso al blanco quebrado o a un blancuzco bajo una atmósfera hermética, encontraba una raíz y motivación filosófica en la literatura Zen que Serrano leía con frecuencia en aquellas fechas, como el clásico El camino del Zen (i957), de Alan Watts, algunos de cuyos párrafos, referidos al pensamiento de Lao-Tse ${ }^{82}$, el pintor reprodujo expresamente en su diario ${ }^{83}$.

Durante la preparación de su segunda exposición individual en la galería Aele (I979), Serrano no buscaba en absoluto una pintura vistosa, sino «una pintura fría y distante, contradictoria, alejada, ante la que no se puedan dar pasos cortos, que sea lo helado y lo tórrido, lo pleno y lo escaso, todo eso que hace que una pintura no sea aprehensible, que sea huidi$\mathrm{za}$, inquietante, individual $»^{84}$; en definitiva, una pintura de aspecto inaccesible y difícil captación, ante la cual el espectador nunca se sintiera cómodo o confortado, viéndose obligado a rodearla, a mirarla de cerca, de lejos y desde varios ángulos: «Un cuadro sin centro geométrico, un cuadro no aprehensible, $\sin$ foco, sin punto de reunión, escurridizo» ${ }^{85}$.

El cuerpo físico de la pintura, extendido sobre el lienzo, debía escapar de los parámetros de nuestra percepción habitual, necesitada de unos focos y ejes bási-

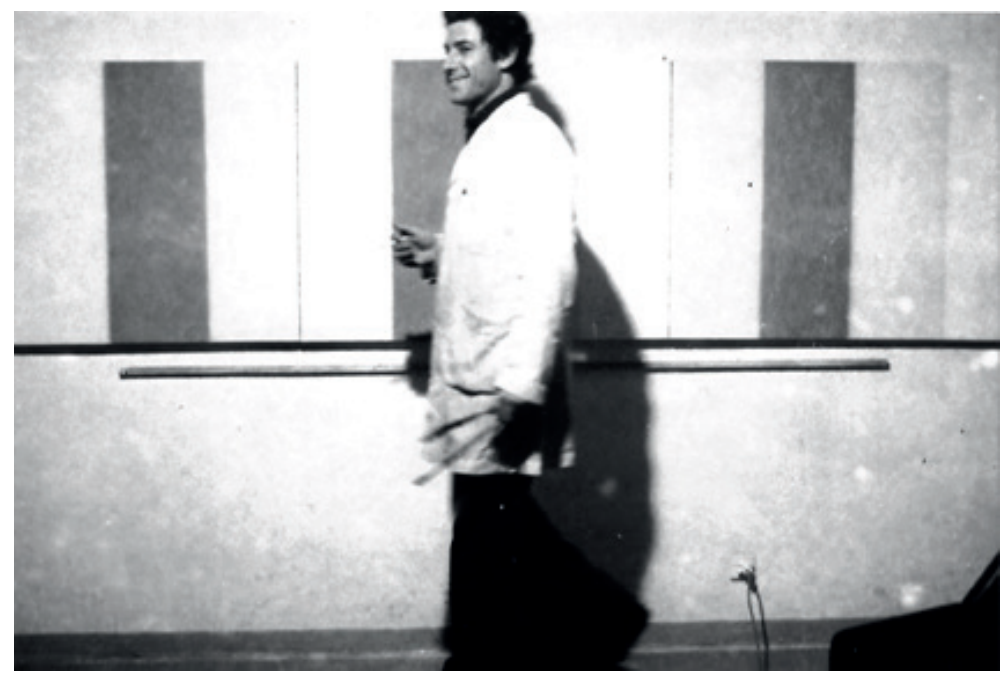

FIGURA 14. SANTIAGO SERRANO EN SU ESTUDIO, 1977 Archivo del artista. cos desde los que poder organizar e interpretar lo que vemos. Si el cuadro carece de centro o centros definidos, ¿quién asimila entonces el papel de centro, de eje?, y sobre todo ¿cómo se establecen las relaciones del espectador con el cuadro y qué tipo de mirada requiere la obra? Una vez formuladas estas preguntas, Serrano llegó a la conclusión de que

el espectador es el eje, y el cuadro gira en torno a él. El discurso roto del cuadro y la falta de «geometría» sitúan al espectador en espectáculo, de modo que el cuadro gira

82. Asimismo, Serrano reprodujo las siguientes frases de Lao-Tse en un cuaderno de trabajo: «Los cinco colores cegarán la vista del hombre / Los cinco sonidos apagarán el oído del hombre / Los cinco sabores arruinarán el paladar del hombre / La caza y la montería tornarán salvaje al hombre / Las cosas difíciles de obtener dañarán la conducta del hombre / Por consiguiente haz provisión para el estómago pero no para los ojos». (ASS), SERRANO, Santiago: Cuaderno, hoja s.f.

83. En la década de los ochenta, Serrano practicó Za Zen en Madrid con dos discípulos de Taisen Deshimaru, autor de libros como Zen y artes marciales y Autobiografía de un monje zen.

84. (ASS), Serrano, Santiago. «Notas» (1973-1994), 31 de marzo de 1979.

85. Idem. 
a su alrededor. La mirada no descansa, sólo puede estar en movimiento, pero huidiza, se escapa lateralmente; él es el cuadro y gira en sí mismo; él, el espectáculo, telón y drama, fantasía y realidad, espejo de sí mismo ${ }^{86}$.

El escape de la pintura hacia los laterales se reflejó en unos formatos rectangulares y alargados, cauce adecuado de una supuesta prolongación de los módulos lumínicos o bandas de color hasta el infinito, en un recorrido curvilíneo que convertiría al espectador en el centro de un imaginario círculo o elipse ${ }^{87}$ (FIGURA I4).

En I979 y I980 Serrano ejecutó varias obras que culminan su ciclo pictórico de los años setenta, si bien desde un enfoque más sensual que el manifestado en las pinturas de los años previos: De la carne (I979), Del amarillo (I980) y Noli me tangere (1980), dípticos todos ellos de $200 \times 300 \mathrm{~cm}$., que fueron incluidos en la emblemática exposición colectiva Madrid D.F. (I980) ${ }^{88}$. El título de la última obra mencionada viene de las frecuentes visitas que Serrano hacía al Museo del Prado, a veces acompañado de Carlos Alcolea, durante las cuales se detenía largos ratos a contemplar el Noli me tangere (ca. I525) de Correggio. Para ambos pintores éste era un cuadro magnético. Les fascinaba la lujuria que sentían palpitar soterradamente en la imagen, así como la belleza apolínea, masculina y sensual que emanaba el cuerpo de Cristo resucitado, en pie ante María Magdalena arrodillada: «un ídolo griego, con unas formas ligeramente redondeadas, pero nada idealizadas, arropado con una túnica de un azul extraordinario que hace valorar más esas carnes un poco amarfiladas pero a la vez vivas» ${ }^{89}$. La pintura de Serrano proviene del impacto sensitivo y estético que le produjo el contacto de ese magnífico color azul con la carne, arropándola ${ }^{90}$.

86. (ASS), Serrano, Santiago: «Notas» (1973-1994), mayo de 1979.

87. Miguel Logroño llamó la atención sobre la capacidad de Serrano de situar al espectador al filo del vacío: «Santiago Serrano reflexiona acerca de tres magnitudes esenciales: color, plano y ritmo. En la primera se sitúa al borde casi de la nada cromática, al borde del no color, blanco, negro y gris. La segunda se erige como por un préstamo geométrico fiado al rectángulo y al cuadrado. Con una y otra área se produce el ritmo, alternativo, cuya progresión sensible llega a alcanzar, a veces, niveles de anulación visual». Logroño, Miguel: «Exposiciones», Diario 16, Madrid, 23 de mayo de 1979.

88. Esta colectiva, celebrada en el Museo Municipal de Madrid, proponía una determinada visión de la pintura española a principios de los ochenta mediante una selección de obras de doce artistas nacidos o afincados en la capital, pertenecientes a un arco generacional amplio pero suficientemente bien definido, que ya había cosechado importantes logros en los años setenta: Juan Antonio Aguirre, Carlos Alcolea, Alfonso Albacete, Miguel Ángel Campano, Eva Lootz, Juan Navarro Baldeweg, Pancho Ortuño, Guillermo Pérez Villalta, Enrique Quejido, Manolo Quejido, Adolfo Schlosser y Santiago Serrano. El título Madrid D. F. / La nueva escena artística madrileña, obedecía al ideal, refrendado por el ayuntamiento de la ciudad, de que Madrid se erigiera en una especie de distrito federal de las artes españolas, «un centro artístico con vocación de universalidad». Véase: «Doce artistas madrileños exponen en el Museo Municipal», El País, Madrid, 2 de octubre de 1980, p. 21. Asimismo: Calvo Serraller, Francisco: «La exposición 'Madrid D.F.' abre las salas del Museo Municipal», El País, Madrid, 15 de octubre de 1980, p. 37; «iQue vienen los federales!», Suplemento Artes El País, Madrid, 25 de octubre de 1980; y SANTOS AmEstor, Dámaso: «No estamos solos», Suplemento Sábado Literario, Pueblo, Madrid, 25 de octubre de 1980, p. 8; «La temporada arranca con Matisse...», Suplemento Sábado Literario, Pueblo, Madrid, 11 de octubre de 1980, p. 8.

89. Entrevista del autor con Santiago Serrano en su estudio, Madrid, 30 de septiembre de 2010.

90. También le atraía la posición inestable de los personajes, la espiral marcada por la postura del Cristo y la tensión que establece la distancia entre las figuras: «Lo sensual del paisaje, lo extremo del color, lo pagano de todo el modelado de las carnes; las frondas del bosque en la lejanía, lujurioso, secreto, mágico y misterioso. Es como una invitación a volar, una 'violación', un super-enamoramiento». (ASS), SERRANO, Santiago: Cuaderno de dibujo, $1977-1980$. 
Serrano extrajo algunas medidas del cuadro de Correggio: largos, anchos, diagonales, y las proporcionó libremente al soporte elegido para construir una composición que, a la vez, reproducía rasgos formales de dípticos suyos anteriores -encuadramientos, respiraderos, franjas laterales, etc.-, especialmente de La bisagra (I978), De la carne (I979) y de varios polípticos alargados de menor tamaño realizados entre I977 y I979; obras en las que había ensayado un planteamiento muy próximo al Colour Field Painting norteamericano - sobre todo, a Barnett Newman-, donde la huella del pincel y de la mano del artista se diluye y desaparece, integrándose en capas de color que, en comparación con los velos de pinceladas rítmicas y verticales que revestían las pinturas de Serrano de 1976 y I977, se expanden ahora con mayor lisura por toda la extensión del lienzo (FIGURA I5) ${ }^{91}$.

Aquel afán por captar lo in-aprehensible y huidizo, aquello que huye de toda captación firme y segura, trascendería la producción de Serrano en los setenta, proyectándose sobre determinados momentos de su trayectoria posterior. Entre ellos, destacaríamos los años I984 y I985, durante los cuales el artista restringió de nuevo drásticamente su registro cromático, oscureciéndolo y situándolo al

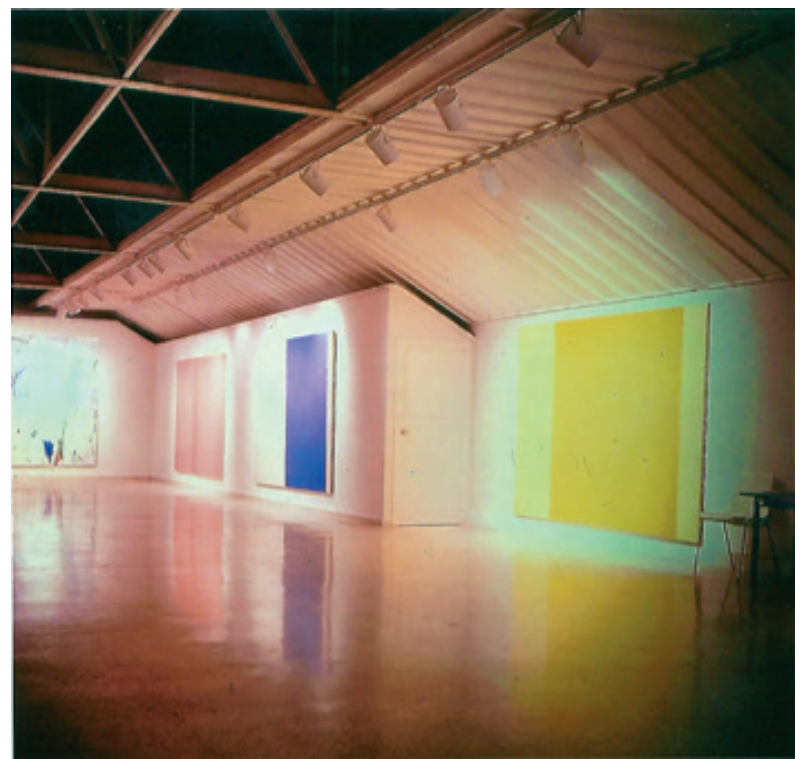

FIGURA 15. DETALLE DE LA EXPOSICIÓN MADRID D.F., MUSEO MUNICIPAL DE MADRID, 1980

En el lado derecho, Del amarillo (1980), Noli me tangere (1980) y De la carne (1979)

Archivo del artista. borde del monocromo. La serie Ancha ceguera (I986-I989), inspirada en la lectura de Sófocles -Edipo-y Borges, nos hace asomarnos a un mundo de contornos imprecisos y tiempo detenido. En la serie Orillas (I998-I999), las manchas y líneas insinúan una vibración apenas perceptible, una sensación de ingravidez e inmaterialidad. Sombra de humo (2005-2006) enlaza con varias observaciones que el artista anotó en su «Cuaderno 1997-2009», acerca de la

91. Gracias a las anotaciones recogidas en un bloc de dibujo, sabemos que en el momento de concebir Noli me tangere Serrano deseaba conjugar un verde-azul —en el que predominara y resplandeciera el azul- con una carnación sensual de un rosa pálido. La combinación produciría una obra en la que «todo es marco de sí mismo, forma y contenido», y en la que se mantendría, destilado hasta lo más esencial, el sentido carnal y a la vez místico que encierra el cuadro de Correggio: «imagen divina de lo humano, de la carne, de las carnes en comunión». (ASS), SERRANO, Santiago: Cuaderno de dibujo, 1977-1980. Serrano terminó la pintura a mediados de junio de 1980, quedándole todavía algunas dudas sobre su resolución más idónea. La composición había sufrido variaciones y no se ajustaba a la idea original de los primeros bocetos: «No sé demasiado de algunas zonas, se me escapan y ahora prefiero esperar a que se pase el tiempo, una ligera espera y veremos». (ASS), SerRANO, Santiago: «Notas» (1973-1994), 17 de junio de 1980. Existen dos versiones de Noli me tangere en óleo sobre lienzo (díptico de $200 \times 300 \mathrm{~cm}$.), así como otra versión en papel, varios bocetos preparatorios y un dibujo que recoge medidas y proporciones, trazado a lápiz, que coincide con la estructura lineal del díptico conservado en el Museo Municipal de Arte Contemporáneo de Madrid. La primera versión, que Serrano considera la más lograda, ha sido incluida en importantes revisiones de la pintura española de los setenta y ochenta como Por la pintura (Diputaciones provinciales de Huesca y Zaragoza, 1991) y Los años pintados (Palacio de Sástago, diputación de Zaragoza, 1994, y Reales Atarazanas de Barcelona, 1995). 
sombra del humo como fenómeno físico y como imagen poética de una situación humana que él mismo no sabría precisar bien, en la que la vida y el espíritu entran en combustión ${ }^{92}$.

En conclusión, durante los años setenta Santiago Serrano respondió a una creciente necesidad interior de tratar el color bajo el punto de vista de sus leyes y propiedades específicas, aunque fuera subvirtiéndolas con el fin de alumbrar situaciones cromáticas inarmónicas y extrañas, en las que al espectador le resultara difícil reconocerse. En aquellos años consideró rigurosamente el color como el ingrediente físico que conforma el cuadro: «Somos ojos-color. La materia no existe separada del color; color y materia son la misma cosa» ${ }^{93}$.

Desde una posición independiente que prima la máxima calidad del objeto artístico, su obra pictórica de I97I se anticipaba de un modo brillante al tipo de abstracción que preconizarían otros pintores en España a partir de I974 - grupo Trama-, quienes con un planteamiento colectivo asumieron parte de los postulados teóricos y políticos del grupo francés Supports/Surfaces. A juzgar por la documentación hallada en su archivo personal, puede decirse que Serrano estuvo más interesado en el desarrollo de la abstracción italiana - a través de artistas como Carmen Gloria Morales y Claudio Verna- que en el modelo francés. Asimismo, su pintura era ajena al informalismo - entonces ya en abierta decadencia- y se diferenciaba claramente de las propuestas del arte abstracto geométrico derivadas del op art, el cinetismo o el minimalismo.

92. (ASS), Serrano, Santiago: «Cuaderno 1997-2009», 9 de septiembre y 1 de noviembre de 2005 . Serrano ya había querido captar lo volátil y huidizo, cualidades propias y definitorias del humo, en su pintura de 1976 a 1978 , cuando investigaba en la plasmación de un color-luz irreal y esquivo como «el sol a través del humo». (ASS), SERRANO, Santiago: «Notas», 1973-1994, 10 de diciembre de 1976.

93. (ASS), Serrano, Santiago: «Notas» (1973-1994), mayo de 1977. 


\section{BIBLIOGRAFÍA (SELECCIÓN)}

Aguirre, Juan Antonio: «Santiago Serrano», Museo Español de Arte Contemporáneo, Ministerio de Cultura, Madrid, mayo-septiembre de I98I.

Alaminos, Eduardo: «Propac. Alcolea, Nacho Criado y Santiago Serrano: Una exposición alternativa, radicalización de una lectura», Artes plásticas, Barcelona, noviembre de I976, n. ${ }^{\mathrm{o}}$ I2, pp. $55^{-57}$.

— «Santiago Serrano: Del cuadro a la superficie», Artes Plásticas, Barcelona, diciembre de I976, n. ${ }^{\circ}$ I3, pp. $83-87$.

— «L'arte in Spagna dopo Franco», Data, Milán, enero/febrero de I978, n. ${ }^{\circ}$ 30, pp. 8-I9.

Aмón, Santiago: «La síntesis suprema de Santiago Serrano», Santiago Serrano, galería Ovidio, Madrid, I973; y Santiago Serrano, sala de arte Ausias March, El Corte Inglés, Barcelona, noviembre de I973.

Calvo Serraller, Francisco: «La pintura de Santiago Serrano», en Santiago Serrano, pinturas, galería Pepe Rebollo, Zaragoza, marzo-abril, i982.

Castro Flórez, Fernando: «Los dones esenciales de Santiago Serrano», Santiago Serrano, galería Ana Serratosa, Valencia, mayo de 2007.

Cereceda, Miguel: «La ética de la pintura de Santiago Serrano», en Santiago Serrano. Silenciario, Fundación Caja Castellón-Bancaja, Castellón, 2007.

DAnvila, José Ramón: «Liturgia de la pintura», en Santiago Serrano, IberCaja/Cultural Rioja, Zaragoza/Logroño, I993.

de Castro Arines, José: «El espacio pictórico de Serrano», Informaciones de las Artes y las Letras, Madrid, 20 de mayo de i97I, p. II.

GÁllego, Julián: «La hora de nona en Santiago Serrano», en Santiago Serrano, obra I988I989, galería Soledad Lorenzo, Madrid, I989.

— «Santiago Serrano, pintor metafísico», ABC de las Artes, Madrid, 28 de septiembre de I989, p. I33; y Santiago Serrano (obra 1988-I990), Colegio Oficial de Arquitectos de Canarias, Delegación de Santa Cruz de Tenerife, marzo-abril de i99o.

Haglund, Elisabet, «Santiago Serrano», en Paletten 3/79, Goteborg, marzo de I979, pp. 32-33.

Hernando Carrasco, Javier: «Expresionismo cromático en España. La lección de Rothko», Goya, I84 (I985), pp. 227-238.

Jarauta, Francisco: «Círculo de posibles», en Santiago Serrano, galería Soledad Lorenzo Madrid, I992.

LOARCE, José Luis: «El valor ontológico de la pintura», Lápiz. Revista Internacional de Arte, Año vı, n. ${ }^{\circ}$ 57, Madrid, marzo de I989, pp. 50-55.

Logroño, Miguel: «Santiago Serrano. Paisaje de la pintura», Diario I6, Madrid, 22 de mayo de I98I, p. 28.

Martín Triana, José María: «Breves notas sobre la obra de Santiago Serrano», Madrid D.F., Museo Municipal, Madrid, I980.

Mayrata, Ramón: «¡Mil Rayos!», El Socialista, Madrid, 28 de diciembre de i983, p. 49.

Moliner, Luis: «Instrumentos de pasión», Santiago Serrano, Centro Cultural del Conde Duque, Ayuntamiento de Madrid, I999, pp. 29-3I.

— «Principios de incertidumbre», Santiago Serrano. Al norte del silencio, Cajastur, Oviedo, 2008. 
Montesinos, Armando: «Días a solas», Diecisiete artistas / Diecisiete autonomías, Junta de Andalucía, 28 de febrero-6 de abril de 1986.

- «Pintura terrenal, imagen ignota», en Santiago Serrano, Galería Joan Prats, Barcelona, I988.

- «La pintura como ensayo», en Santiago Serrano, Sala de Arte Robayera, Miengo (Cantabria), mayo de 2002.

Moreno Galván, José María: Santiago Serrano 72-73, galería Grosvenor, Madrid, abril de I973.

— «Santiago Serrano», Triunfo, Año xxvill, n. ${ }^{\circ}$ 576, Madrid, I3 de octubre de I973, pp. 79-80.

MUÑoz SÁNCHEZ, Óscar: «Santiago Serrano: Instrumentos para un arte gráfico», Grabado y Edición (revista bimestral especializada en grabado y ediciones de arte), n. ${ }^{\circ}$ I3, San Lorenzo del Escorial, marzo de 2008, pp. 20-27.

- «Cajas de arte gráfico digital: un gabinete privado», Santiago Serrano: ediciones de gráfica digital, Museo del Grabado Español Contemporáneo, Marbella, 2012.

- «Casas de hueco y memoria», en La casa delata. Santiago Serrano, Museo de la Fundación Gregorio Prieto, Valdepeñas, 2013.

Navarro, Mariano: «Santiago Serrano», El Socialista, Madrid, 28 de diciembre de I983, p. 48.

- «Santiago Serrano: la sombra de la mirada», en Santiago Serrano, Centro Cultural del Conde Duque, Ayuntamiento de Madrid, Madrid, I999, pp. 15-28.

- «Egam cumple 35 años / Santiago Serrano. De los nombres del cuadro», en Siete lustros de la galería Egam, Egam, Madrid, 2004.

Pezzoni, Enrique: Santiago Serrano, galería Snob, Buenos Aires, I97I.

- Santiago Serrano, sala de Arte Ausias March, Barcelona, I973.

Rivas, Francisco: «Santiago Serrano», El País, Madrid, I7 de mayo de I979.

Rodríguez, Ángel Antonio: «Al norte del silencio», Santiago Serrano. Al norte del silencio, Cajastur, Oviedo, 2008.

Rubio Nomblot, Javier: «La ceniza y la letra», Santiago Serrano, Ediciones Universidad de Salamanca, Salamanca 2006.

Santos Amestoy, Dámaso: «Gravedad, transparencia, penumbra...», Sombra de humo, Fundación Colegio del Rey, Alcalá de Henares, 2007.

Urbina, Pedro Antonio: Santiago Serrano, galería Amadís, Madrid, I97I.

- Santiago Serrano, sala de arte Ausias March, El Corte Inglés, I973. 


\section{Dossier Cómplices Necesarios por Carlos Reyero Hermosilla - Dossier Necessary Accomplices by Carlos Reyero}

2) CARLOS REYERO

Introduction: Necessary Accomplices / Presentación: Cómplices necesarios

25 Encarna Montero Tortajada

The Oligarch and the Brushes: a Biographical Sketch of Andreu Garcia, priest / El oligarca y los pinceles: breve semblanza del presbítero Andreu Garcia

María Alegra García García

Some aspects about archbishop of Toledo don Juan Martínez Silíceo's iconography (c.1477-1557) / Algunos aspectos en torno a la iconografía del arzobispo de Toledo don Juan Martínez Silíceo (c.1477-1557)

\section{FELIPE PEREDA}

Performing Doubt: the Art of Believing in Early Modern Spain / El ejercicio de la duda: el arte de creer en la España alto Moderna

\section{Jesús-PEdRo LoREnTE LORENTE}

The mouseion ideal reinterpreted as art colony on the outskirts of Darmstadt and Hagen / El ideal del mouseion reinterpretado como colonia artística en las afueras de Darmstadt y Hagen

\section{9}

NÚRIA FERNÁNDEZ RIUS \& NURIA PEIST

The photographic and the mediation system. Artistic, technical and commercial values in the beginning of photography / Lo fotográfico y el sistema mediador. Valores artísticos, técnicos y comerciales en los inicios de la fotografía

\section{Elena Marcén Guillén}

Real museum, imaginary museum. Considerations around the concept of museum as metamorphosis scenery / Museo real, museo imaginario. Reflexiones en torno al concepto de museo como escenario de metamorfosis

147 VICENÇ FURIÓ

Fame and prestige: necessary and decisive accomplices in the case of Hilma af Klint / Fama y prestigio: cómplices necesarios y decisivos en el caso de Hilma af Klint

\section{Miscelánea $\cdot$ Miscellany}

De la aljama a la primitiva construcción gótica. Reflexiones a propósito de la Catedral de Jaén en época bajomedieval / From the Great Mosque to the former Gothic construction. Some observations on Jaén's Cathedral during the late middle ages
199

TERESA IZQUIERDO ARANDA

Carpintero y maestro constructor en la arquitectura gótica valenciana / Carpenters and building mason in the Gothic architecture in Valencia $\left(14^{\text {th }}-15^{\text {th }}\right.$ centuries)

223

ANTONIO JosÉ DíAZ FERNÁNDEZ

El arquitecto madrileño Pedro de la Torre en Toledo y un retablo inédito localizado / The Architect of Madrid Pedro de la Torre in Toledo and a located unpublished altarpiece

24.7 Fernando R. Bartolomé García \& Laura Calvo García

Transformaciones en el retablo mayor de San Miguel Arcángel de Lazkao (Gipuzkoa). Del Barroco al Neoclasicismo / Changes in the main altarpiece of Saint Michael the Archangel in Lazkao (Gipuzkoa). From Baroque to Neoclassicism

\section{Francisco JaVIER LÁZARO SEBAStiÁN}

La renovación de la fotografía española a partir de la pauta estética del realismo. Un precedente formal y significativo en el reportaje de Eugene Smith sobre Deleitosa (Cáceres) / The renovation of the Spanish photography from the aesthetic guideline of the realism. A formal and significant precedent in Eugene's Smith photographic article on Deleitosa (Cáceres)

277 Javier Cuevas del Barrio

El posicionamiento de Sigmund Freud ante el Surrealismo a través de la correspondencia con André Breton / The position of Sigmund Freud regarding Surrealism through correspondence with André Breton

295 Alicia SÁnCHEZ ORTIZ

El vacío iluminado del negro / The illuminated void of black

317 Óscar MuÑoz Sánchez

Santiago Serrano (1970-1980): Hacia una pintura no aprehensible / Santiago Serrano (1970-1980). Towards a non-apprehensible painting

347 Antonio Jesús Sánchez FERnÁndeZ

Restauración y metamorfosis de los valores del patrimonio cultural / Restoration and Metamorphosis of the Values of Cultural Heritage

\section{Reseñas · Book Review}

375

Aricò, Nicola. Architettura del Tardo Rinascimento in Sicilia. Giovannangelo Montorsoli a Messina (1547-57). Firenze, Leo S. Olschi Editore, 2013. (AlICIA CÁmARA MuÑoz)

Combalía, Victoria. Dora Maar. Barcelona, Circe, 2013. (AMPARO SERRANO DE HARO)

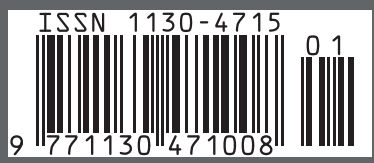

